NBER WORKING PAPER SERIES

\title{
IDIOSYNCRATIC RISK AND THE CREATIVE DESTRUCTION IN JAPAN
}

\author{
Yasushi Hamao \\ Jianping Mei \\ Yexiao Xu \\ Working Paper 9642 \\ http://www.nber.org/papers/w9642
NATIONAL BUREAU OF ECONOMIC RESEARCH 1050 Massachusetts Avenue
Cambridge, MA 02138
April 2003

\begin{abstract}
We would like to thank Stephen Brown, Jennifer Carpenter, Kalok Chan, Lewis Chan, Gregory Chow, John Griffin, John Heaton, Jean Helwege, David Hirshleifer, Burton Hollifield, Douglas Joines, Andrew Karolyi, Donna Keyser, Burton Malkiel, René Stulz, Jessica Wachter, Karen Wruck, Jeff Wurgler, and participants at NBER Japan Project Meeting, $13^{\text {th }}$ Annual Conference in Financial Economics and Accounting at University of Maryland, and seminars at City University of Hong Kong, Hong Kong University of Science and Technology, New York University, Ohio State University, University of Southern California for helpful discussions and suggestions. The views expressed herein are those of the authors and not necessarily those of the National Bureau of Economic Research.
\end{abstract}

C2003 by Yasushi Hamao, Jianping Mei, and Yexiao Xu. All rights reserved. Short sections of text not to exceed two paragraphs, may be quoted without explicit permission provided that full credit including Cnotice, is given to the source. 
Idiosyncratic Risk and the Creative Destruction in Japan

Yasushi Hamao, Jianping Mei, and Yexiao Xu

NBER Working Paper No. 9642

April 2003

JEL No.G2

\section{$\underline{\text { ABSTRACT }}$}

The dramatic rise and fall of the Japanese equity market provides a unique opportunity to examine market-and firm-specific risks over different market conditions. The price behavior of Japanese equities in the 1990s is found to resemble that of U.S. equities during the Great Depression. Both show increasing market volatility and a prolonged large co-movement in equity prices. What is unique about the Japanese case is the surprising fall in firm-level volatility and turnover in Japanese stocks after its market crash in 1990. This large decrease in firm-level volatility may have impeded Japan's capital formation process as it has become more difficult over the past decade for both investors and managers to separate high quality from low quality firms. Using data on firm performance fundamentals and corporate bankruptcies, we show that the fall in firm-level volatility and turnover in Japanese stocks could be attributed to the sharp increase in earnings homogeneity among Japanese firms and the lack of corporate restructuring.

Yasushi Hamao

Marshall School of Business University of Southern California hamao@usc.edu
Jianping Mei

Stern School of Business

New York University jmei@stern.nyu.edu
Yexiao Xu

School of Management University of Texas at Dallas yexiaoxu@utdallas.edu 
It was the best of times, it was the worst of times, it was the age of wisdom, it was the age of foolishness, it was the spring of hope, it was the winter of despair, we had everything before us, we had nothing before us, we were all going direct to Heaven, we were all going direct the other way. -Charles Dickens, "A Tale of Two Cities"

The chronic stagnation of the Japanese economy is a big puzzle. Once a shining light for both developing and industrialized nations, it has now become a basket case for bubble economies. Twelve years after its stock market bubble burst, a once mighty country is still operating far below its potential productive capacity. While numerous arguments have been advanced to explain the recent plight of the Japanese economy, most have focused on lack of consumer demand, collapsing asset values, and nonperforming loans. ${ }^{1}$ This paper offers a unique perspective by studying the role of Japanese equity markets. A comparison of the Japanese case to the U.S. market during the Great Depression reveals important similarities and differences that may contribute to our understanding of the prolonged economic stagnation in Japan. Specifically, while there are great similarities in the market volatility and correlation structure of equities, the behavior of firm-specific volatility of Japanese equities exhibits important differences.

Campbell, Lettau, Malkiel, and Xu (2001) were the first to provide a comprehensive study of idiosyncratic risk for U.S. stocks. During the period from 1962 to 1997 , they discovered a noticeable increase in firm-level volatility relative to market volatility. Moreover, they found that all volatility measures (market, industry, and firm) move together counter-cyclically in the U.S. In other words, firm-level volatility tends to increase during a recession. In contrast to the U.S. experience, this paper reports a sharp

\footnotetext{
${ }^{1}$ See for example, Krugman (1999).
} 
reduction in firm-level volatility immediately following the Japanese market crash, and an increase in market-wide volatility.

In order to understand the abnormal behavior of idiosyncratic risk in Japan, we examine the impact of firm performance fundamentals as well as bankruptcy on firmlevel volatility. We find that fundamental performances of firms are tied more closely together during the post-crash period. We also discover a positive correlation between changes in aggregate firm-level volatility and corporate bankruptcies. There is some circumstantial evidence that increasing bankruptcies after 1997 have led to higher firmlevel volatility. In addition, we find idiosyncratic volatility for firms with business group affiliations is less responsive to economic conditions than that of firms without such affiliations. All these results suggest that the sharp fall in firm-level volatility could be due to group protection.

This anomalous behavior of firm-level volatility may help us understand the poor performance of the Japanese economy over the last decade. Disaggregated volatility measures could impact aggregate output in several ways.

First, macroeconomic models of "cleansing recessions," such as those described by Caballero and Hammour (1994) and Eden and Jovanovic (1994), emphasize the impact of firm-level volatility on resource allocation during recession. A recession may increase the arrival rate of information about management quality and thus increase resource reallocation from low quality to high quality firms. Such resource reallocation is enhanced in the U.S. because firm-level volatility moves counter-cyclically. To the extent that Japanese market downturns are accompanied by a reduction in firm-level 
volatility, it makes it more difficult for investors to distinguish low quality from high quality firms, thereby reducing the effectiveness of the cleansing mechanism.

Second, recent finance studies demonstrate that a reduction in firm-level volatility may affect the capital allocation process. Wurgler (2000) presents evidence that countries with stock markets that impound more firm-specific information into individual stock prices exhibit a better allocation of capital. Wurgler suggests that efficient secondary market prices can help investors and managers distinguish good investments from bad ones. ${ }^{2}$ Durnev, Morck, and Yeung (2001) also find that firms in industries with greater firm-specific return variation exhibit a higher quality of capital budgeting, in that their profitability indices (marginal Q ratios) are closer to one (or to a tax-adjusted benchmark).

This paper builds on the growing literature exploring the relationship between financial markets and economic growth. ${ }^{3}$ While it is based on the methodology developed by Campbell, Lettau, Malkiel, and Xu (2001), we have introduced a number of innovations. First, we broaden the approach by considering volatility behavior under different economic conditions. Second, we use firm-level volatility in the Japanese market to study the capital allocation issue in down markets. Third, we extend the work of Campbell, Lettau, Malkiel, and Xu (2001) to cover the U.S. market during the19281946 time period.

\footnotetext{
${ }^{2}$ See also Morck, Yeung, and Yu (2000) and Durnev, Morck, Yeung, and Zarowin (2002).

${ }^{3}$ King and Levine (1993), Levine (1998), Levine and Zervos (1998), Beck, Levine, and Loayza (1999), Demirguc-Kunt and Maksimovic (1998) demonstrate that firms in financially developed countries grow faster. Rajan and Zingales (1998) show that industries that are externally financed grow faster in financially developed countries. Jayaratne and Strahan (1996) discover that economic growth increases in states that have less stringent intrastate banking restrictions.
} 
The remainder of this paper is organized as follows. Section I provides a brief description of the data and the various specifications for estimating firm-specific volatilities, including a simple market model, the Fama and French (1993) three factormodel, the Xu and Malkiel (2001) approach, as well as a multi-factor APT model. Section II presents our main empirical results. In Section III we explore relations between firm-level volatility and institutional features unique to Japan, such as keiretsu and the main bank system. Section IV describes the implications of the findings, particularly in comparison with the pre-WWII U.S. market. Section V offers concluding comments.

\section{Measuring Idiosyncratic Volatility}

\section{A. Data and Background}

Much of modern finance theory strives to establish a quantitative relationship between risk and return. In some sense, the success of each theory hinges on measuring risk. In general, there are two types of risks for individual securities: systematic risk, which is determined by common risk factors; and idiosyncratic risk, which is the residual risk. Since idiosyncratic risk can be diversified in standard finance theory, its role has been largely ignored. Campbell, Lettau, Malkiel, and Xu (2001) suggest that idiosyncratic volatility has increased substantially over the past decade due to the trading behavior of institutional investors and the pursuit of growth objectives by many individual companies (see also Xu and Malkiel, 2001). In this paper, we take a new look at the evolution of idiosyncratic risk after the Japanese market crash. 
In order to examine all stocks listed on the First and Second Sections of the Tokyo Stock Exchange (TSE), we draw on data from different sources. Monthly data on individual stock returns and volume and annual financial statements (for book value of equity) are from the PACAP Japan database. Short-term interest rates are from updates of the database presented in Hamao (1991). GDP and industrial production data are from the Japanese Ministry of Economy, Trade, and Industry. The Nomura Research Institute and Tokyo Shoko Research provide bankruptcy data.

This study covers the period from 1975 to 1999 . The entire sample period is divided into five 5-year periods. The first two periods (1975-1979 and 1980-1984) are before the bubble; the third (1985-1989) is the bubble period, and the last two periods (1990-1994 and 1995-1999) correspond to the post-crash era. The numbers of stocks in each sub-period are $1174,1275,1368,1521$, and 1607 , respectively.

While a thorough account of Japanese economic history during this sample period is beyond the scope of this paper, we provide a brief summary of events as background information.

After a post-World War II high-growth period (1956-1973, average annual GDP growth rate of 9.2\%), Japan entered a lower growth period, triggered by the oil crises. The average annual GDP growth rate during the period from 1974 to 1990 was 3.8\%. Our sample period starts in 1975, which is around the beginning of this medium-growth period. In the latter period of our sample, Japan's growth rate dropped further to an average of 1.3\% (1991-2000). This low- or no-growth period corresponds with the aftermath of the crash of the financial market bubble. 
Soon after the Plaza Accord of 1985, the value of the yen rapidly appreciated against the U.S. dollar from 250yen/\$ in May 1985 to 170 yen/\$ in May 1986, and then to 144yen/\$ in May 1987. Facing such currency appreciation, Japan, traditionally dependent on exports, needed to stimulate domestic demand in order to avoid recession. The Bank of Japan took a decidedly low interest rate policy. The official discount rate was lowered to $2.5 \%$ in February 1987 and was not raised until 1989. In addition to this expansive monetary policy, credit in general was easy to obtain. Banks were heavily protected by the Ministry of Finance through the so-called "convoy system," which essentially guaranteed that no bank would fail. Given this implicit government guarantee and the loose corporate governance that resulted from cross-shareholding, the Japanese banking system found itself in a situation of moral hazard. Banks and their affiliated financial institutions easily funded stock and land speculators as well as businesses with optimistic expansion plans. Stock and land prices soared, but the general price level remained stable.

Interest rates were finally raised in 1989 and 1990 in order to contain the bubble. The market started to crash in 1990, and bank balance sheets deteriorated with bad loans. Since then Japan has been slow in dealing with the problems that arose in the aftermath of the bubble collapse. Although the banking problem had been well recognized since the early 1990s, it was not publicly acknowledged until the first failure of a major bank (Hokkaido Takushoku Bank, in November 1997). In late 1998, two more major banks (Long-Term Credit Bank and Nippon Credit Bank) ultimately failed and were nationalized. In March 1998, 15 major banks reluctantly received injections of tax money totaling 7.45 trillion yen. The bad loan problem has not improved much since 
then, as the economy went into another round of recession. Ongoing discussion of the necessity of a second round of bank bailouts continues. The public press often refers to the 1990s as Japan's "lost decade."

\section{B: Model Specification}

Since our study focuses on idiosyncratic risk, we use idiosyncratic volatility to measure it directly. Unlike total volatility, uncovering idiosyncratic volatility requires the use of an asset pricing model. As a start, we use the popular market model to decompose the total return into systematic and idiosyncratic components. That is, we run the following model,

$$
R_{i, t}-R_{f, t}=\alpha_{i}+\beta_{m, i}\left(R_{M, t}-R_{f, t}\right)+\varepsilon_{i, t},
$$

where $R_{i, t}, R_{M, t}, R_{f, t}$ are the individual stock return, the value-weighted market return, and the risk-free rate, respectively. We measure idiosyncratic volatility using the root mean square of residuals, $\varepsilon_{i, t}$.

The market model may be misspecified if we fail to measure the market return or if other risk factors exist, as suggested by the APT model. Despite the fact that we cannot perfectly rationalize the factors used in Fama and French (1993), their three-factor model is considered as "state of art" from an empirical perspective. Furthermore, Chan, Hamao, and Lakonishok (1991) and Daniel, Titman, and Wei (2000) document that size and book-to-market ratio are significant determinants of the cross-section of Japanese stock returns. Therefore, we will also use the three-factor model to decompose the total return as,

$$
R_{i, t}-R_{f, t}=\alpha_{i}+\beta_{m, i}\left(R_{M, t}-R_{f, t}\right)+\beta_{S M B, i} R_{S M B, t}+\beta_{H M L, i} R_{H M L, t}+\varepsilon_{i, t},
$$


where $R_{S M B, t}, R_{H M L, t}$, are the return proxies for the size variable and the book-to-market variable, respectively. Again, idiosyncratic volatility is computed as the root mean square of residuals, $\varepsilon_{i, t}$. We have followed the exact procedure of Fama and French (1993) to construct the two proxies for the size and book-to-market variables.

Campbell, Lettau, Malkiel, and Xu (2001) have proposed a model-free decomposition procedure based on daily data. This approach applies only to computing the total aggregate idiosyncratic volatility, which is the focus of this paper. Since this study uses monthly stock returns, we follow a modified approach developed by Xu and Malkiel (2001). Specifically, the total aggregate volatility $\sigma_{T V}^{2}$ is calculated by value weighting an individual stock's total volatility $\sigma_{i, T V}^{2}$. The aggregate idiosyncratic volatility $\sigma_{I V}^{2}$ is then computed as the difference between the total aggregate volatility and the market volatility. ${ }^{4}$

Whether we use the market model or the Fama and French three-factor model, it is still possible that our measurement of idiosyncratic volatility includes other missed factors. Therefore, we extend our analysis by utilizing multi-factor asset pricing models. Recent empirical work by Cremers and Mei (2002) shows a close relationship between idiosyncratic volatility and turnover in the U.S. data. To confirm our results regarding Japanese idiosyncratic volatility, this paper also applies the duo-factor model of Lo and Wang (2000) in constructing idiosyncratic volatility and turnover measures. (See appendix for details and the estimation procedure).

\footnotetext{
${ }^{4}$ Since volatilities in general are unobservable, we apply rolling statistics as used in Xu and Malkiel (2001) to estimate them efficiently. The optimal weights are suggested by Foster and Nelson (1999) with a functional form of $\mathrm{e}^{-\alpha \mathrm{t}}$, where $\alpha \mathrm{T}=\sqrt{3}$. In particular, we choose window length $\mathrm{T}=12$ for our monthly return as suggested in $\mathrm{Xu}$ and Malkiel (2001). This approach estimates both the total volatility and the market volatility.
} 


\section{Time-Varying Market Volatility and Idiosyncratic Volatility}

A fascinating fact about the post-1962 U.S. equity market is that, while the overall market seems relatively calm, idiosyncratic volatility has shown a steady increase over the past decade. Although the financial world has become increasingly integrated, the Japanese equity market has gone through different cycles. It is therefore of interest to examine this issue with respect to the Japanese equity market.

\section{A. Examining the Overall Market}

We first plot aggregate returns and trading volume of the Tokyo Stock Exchange. As Figure 1 illustrates, the market experienced a rapid run-up after 1985, and it peaked in December 1989. This period, now widely known as the "bubble period," was followed by a rapid decline of the market and a consequent series of ups and downs. For simplicity, we will call the 1990-1994 period "the crash period" and the 1995-1999 period "the post-crash period." In the 1990 s, the index value stayed between $1 / 2$ to $2 / 3$ of its peak and there was a sharp fall in trading volume.

\section{[Insert Figure 1 approximately here]}

Table 1 provides summary statistics of the data. The first item reported in Table 1 is the mean and standard deviation of the value-weighted market return $\left(R_{M}\right)$. The mean market return is positive in the first three periods, with a high $2.8 \%$ per month return in the 1985-1989 period. In the last two periods, however, the market on average earned negative returns. The standard deviation of market return shows a rising trend. Next, we report the cross-sectional median, mean, and standard deviation of individual 
stock returns averaged over time $\left(\bar{R}_{i}\right)$. The mean and median of $\bar{R}_{i}$ show a similar pattern to that of the market return, but the standard deviation does not have a clear-cut trend as the market index does.

\section{[Insert Table 1 approximately here]}

The next three columns of Table 1 report the results of the market model estimation for individual stocks. We first notice a significant reduction in the crosssectional variation of firm betas, $\beta_{\mathrm{i}, \mathrm{CAPM}}$, from 0.447 to 0.321 from the bubble period to the crash period. We also note a remarkable change in the $\mathrm{R}^{2}$ of the market model. On average it is $13 \%$ and $10 \%$ in the earlier, pre-bubble periods, but increases to $17 \%$ during the bubble period, and jumps dramatically to $51 \%$ in the period immediately following the market peak. Although it decreases somewhat in the last period, the market model explains on average $39 \%$ of the variation of individual stocks.

One might suspect that the market "bubble" caused stocks to move in the same direction, as investors in general may have expected similar returns on stocks with different characteristics. But the further increased explanatory power of the valueweighted index after the burst of the bubble indicates that Japanese stocks started to move together with the whole market, even when the market started to decline and the economy suffered from recession. In these years, individual stocks lost much of their contribution of idiosyncratic risk to total risk. This is in contrast to results obtained in the U.S. as reported by Campbell, Lettau, Malkiel, and Xu (2001), who find that firm-level volatility is higher in NBER-dated recessions.

The sixth column in Table 1 shows the cross-sectional distribution of the idiosyncratic component of volatility $\left(\sigma_{i, I}\right)$, as measured by the mean square of 
residuals. We note a slightly increased idiosyncratic volatility in the bubble period (0.106), followed by a sharp fall to 0.080 in the crash period, and then a recovery to 0.093 in the post-crash period. In addition, we observe more than a 50\% decrease in the variation of $\sigma_{i, I V}$ during the crash period, dropping from 0.039 to 0.024 . Total volatility $\left(\sigma_{i, T V}\right)$ reported in the seventh column is the return volatility of individual stocks measured over each period. While total volatility changed little from the bubble to the post-crash periods, we notice a $25 \%$ drop in the variation of $\sigma_{i, T V}$ during the crash period, falling from 0.038 to 0.029 .

Table 1 also presents summary statistics for market capitalization and turnover. The size of Japanese companies increased during the first four periods, but decreased in the last period. Average turnover $\overline{\eta_{i}}$ of stocks was high (0.056) until the collapse of the bubble (1989) and then decreased significantly to 0.027 afterwards. In addition, there is also a significant drop in the variation of $\overline{\eta_{i}}$, changing from 0.039 in the bubble period to 0.022 in the crash period. The simultaneous fall in $\sigma_{i, I V}$, the variation of $\sigma_{i, T V}$, and the variation of $\overline{\eta_{i}}$ all suggest a much stronger presence of the market factor in both stock returns and trading volume during the crash period.

To further investigate the significant shift in the characteristics of Japanese firms during the bubble-burst period, we performed simple mean tests for levels and $\mathrm{F}$ tests for variances for each sub-period in comparison with the bubble-burst period. The results of these tests are presented in Table 2. First, as evidenced by the low variation in beta (see third column in Table 2), differences among systematic risk of individual firms appear to have dropped significantly. At the same time, both the level of aggregate idiosyncratic 
volatility and the differences in idiosyncratic volatilities among different firms have gone down significantly over this period. This suggests that each firm's contribution to market risk and its innovative activities are alike.

[Insert Table 2 approximately here]

\section{B. The Dynamic Behavior of Market and Idiosyncratic Volatility}

The summary statistics provide a strong indication of the differences in behavior of the volatility components. Figure 2 shows the 12-month moving average of both the monthly market volatility and the monthly aggregated idiosyncratic volatility. Through this visual presentation, we can detect a trend of increasing market volatility (the solid line) with a large jump at the time of the crash in 1990/1991. Consistent with the summary statistics presented in Table 1, volatility increased during the bubble period as compared to previous years, and remained higher during the period of market decline in the 1990s.

\section{[Insert Figure 2 approximately here]}

While market-wide volatility in Japan appears to have increased after 1985, we also see a decreasing trend in the behavior of idiosyncratic volatility. There is, however, a noticeable jump in the last two years, during the period when the Japanese financial system experienced unprecedented stress and reorganization (e.g., bank failures and government bailouts). ${ }^{5}$ Aggregate trading volume was also higher during the boom period, but since then has decreased to the lowest level in the entire sample. These figures are shown in Figure 1 in monthly frequency.

\footnotetext{
${ }^{5}$ Kang and Stulz (2000) document that bank-dependent firms suffered more than others in Japan in early 1990 s.
} 
Both market and aggregated idiosyncratic volatilities seem to be quite persistent. The observed trends may be due to persistency in the data, or the volatilities could be non-stationary. Therefore, a careful econometric analysis is necessary for drawing any definite conclusions. Since volatility is non-negative, we test the unit root hypothesis on $\log$ volatilities. In particular, the following model is estimated in order to apply the augmented-Dickey-Fuller test:

$$
\ln \left(\sigma_{\mathrm{t}}\right)=\mu+\rho \ln \left(\sigma_{\mathrm{t}-1}\right)+\gamma \mathrm{t}+\alpha_{1} \Delta \ln \left(\sigma_{\mathrm{t}-1}\right)+\ldots+\alpha_{6} \Delta \ln \left(\sigma_{\mathrm{t}-\mathrm{\sigma}}\right)+\varepsilon_{\mathrm{t}} .
$$

We first study the whole sample period from 1975 to 1999 . Since most of the abnormal behavior in idiosyncratic volatility occurs in the post-bubble era, we also test idiosyncratic volatility for the sub-sample period from 1985 to 1997. All results are reported in Table 3. Apparently the second stock market crash in October 1990 had a larger impact than the first crash in October 1987. This raises the issue of whether this one-time event may be overshadowing the rest of the sample and distorting some of the results. In order to reduce the impact of this outlier, we replace the October 1990 observation with the second largest observation in the data set. This admittedly ad hoc procedure allows us to decrease the influence of the crash while allowing it to remain in the sample as an important event.

[Insert Table 3 approximately here]

For market volatility, the augmented Dickey-Fuller test clearly rejects the unit root hypothesis at a $5 \%$ significance level, which means that market volatility is in fact stationary. At the same time, the linear trend is positive and statistically significant at a $1 \%$ level. Thus, in contrast, the aggregate idiosyncratic volatility $\ln \left(\sigma_{\mathrm{IV}}\right)$ appears to be non-stationary, with augmented Dickey-Fuller test statistics of -18.75 compared with the critical value of -24.5. In addition, the trend coefficient is not statistically different from 
zero. This conclusion is robust to different specifications of idiosyncratic volatility measures, such as $\ln \left(\sigma_{\mathrm{CAPM}, \mathrm{IV}}\right)$ and $\ln \left(\sigma_{\mathrm{FF} 3 \mathrm{~F}, \mathrm{IV}}\right)$, as shown in Table 3.

As Figure 2 shows, idiosyncratic volatility has behaved very differently in the post-bubble period. The augmented Dickey-Fuller test strongly rejects the unit root hypothesis. At the same time, there is a statistically significant downward trend in the idiosyncratic volatility. This is also robust to other measures of idiosyncratic volatilities. Therefore, while the aggregate stock market volatility in Japan has trended upwards over the years, firm-level volatility decreased during the 1990s, except for two short episodes coinciding with the rapid decline of the market in1990/91, and the bank failures in 1998 .

\section{Rising Correlation among Stock Returns and Turnover}

Although the evidence on decreasing idiosyncratic volatility and increasing market volatility is strong, we can further examine the issue from the perspective of the explanatory power of the market model, which is the $\mathrm{R}^{2}$ measure. ${ }^{6}$ Apparently, the dispersion between market volatility and idiosyncratic volatility implies an increase in the $\mathrm{R}^{2}$ for the market model. In Figure $3 \mathrm{a}$, we show the dynamics of average $\mathrm{R}^{2}$ statistics from the market model. $\mathrm{R}^{2} \mathrm{~s}$ for both returns and turnover are reported. At time $\mathrm{t}$, the return $\mathrm{R}^{2}$ is computed based on estimating the market model using the previous 24 months of monthly data, and the turnover $\mathrm{R}^{2}$ is computed in a similar way from a single factor model. We can see the return $\mathrm{R}^{2}$ s peaked during 1994-1995 and then declined in the most recent years, but still remain higher than the level of the 1970s and 1980s.

\section{[Insert Figure $3 a$ and $3 b$ approximately here]}

\footnotetext{
${ }^{6} \mathrm{R}^{2}=1$-(idiosyncratic volatility)/(total volatility). Recently, there is an increasing application of average $\mathrm{R}^{2}$ as a measure of market information inefficiency (see Morck, Yeung, and Yu, 2000; Durnev, Morck, Yeung, and Zarowin, 2002; and Wurgler, 2000). Higher $\mathrm{R}^{2}$ implies that the market is less informationally efficient.
} 
Perhaps it is more interesting to examine the changing volatility issue from the correlation perspective. If market volatility reflects the average covariance among individual stock returns, the observed phenomenon of decreasing idiosyncratic volatility could only happen when the average correlation increases. We present correlations among individual stock excess returns and volume in Figure 3b. At any time t, we compute the average of pair-wise correlations using the previous 24 months of monthly data. As the figure shows, we find a clear pattern in the evolution of return and volume correlations: approximately 0.10 for returns and 0.05 for volume in the $1970 \mathrm{~s}$ and $1980 \mathrm{~s}$. But in the 1990s, after the collapse of the bubble, the correlations increase significantly, to as high as 0.50 for returns, and 0.20 for volume.

The correlation picture uncovers important characteristics about the Japanese market. During the decline of the market and the contraction of the economy, stocks in the Japanese market lost their individuality and started to move together, making it more difficult to separate the good firms from the bad. Faced with stocks that were not very distinguishable from each other, more and more companies were treated like "lemons" by Japanese market investors. This behavior may have prevented capital from flowing into good companies to support innovations and continued competitiveness, thus weakening their ability to sustain economy-wide shocks. The resulting increased vulnerability of firms may have induced higher overall market volatility. As Figure 2 suggests, Japanese investors have faced rising aggregate market risk in the 1990s.

\section{Idiosyncratic Risk and $R^{2}$ in a Multi-Factor Model}


We now confirm the above results by explicitly testing the duo-factor model (outlined in the Appendix) using monthly returns and turnover data for TSE securities from 1975 to 1999 . Table 4 provides the results of the test across a number of factors in excess return and turnover, including incremental $\mathrm{R}^{2}$ from the $\mathrm{k}$-th factor of the return and turnover for models for 1 to 10 factors. The first principal component of returns explains $14 \%$ and $11 \%$ of the normalized excess returns in the 1975-1979 and 1980-1984 periods, which increases to $18 \%$ during the bubble period, followed by dramatic increases to $52 \%(1990-1994)$ and 39\% (1995-1999) in the post-bubble periods. These findings indicate that during a period of market decline, excess returns are largely driven by a single systematic factor, and are consistent with our previous results showing rising market risk during the post-bubble period. ${ }^{7}$

[Insert Table 4 approximately here]

The last column of Table 4 shows the average $\mathrm{R}^{2}$ of regressing individual stock returns and turnover on their corresponding systematic factors for each period. In the first period, a three-factor model explains on average $25 \%$ of variation of stock returns and a four-factor model explains $31 \%$ of variation of turnovers. These $\mathrm{R}^{2} \mathrm{~s}$ go up slightly for the 1985-1989 period, suggesting a small rise in commonality in time-series variations of both stock returns and volumes. However, we find a significant increase in average $\mathrm{R}^{2} \mathrm{~s}$ in the 1990-1994 and 1995-1999 periods for both returns and turnovers. This indicates that during the post-bubble period, there is a sharp decrease in contribution

\footnotetext{
${ }^{7}$ Table 4 also reports the number of factors in excess returns and turnover, determined by using a loss function suggested by $\mathrm{Xu}$ (2001). Our results show that there are 3 factors in excess returns in Japan, except for the 1990-94 period where there are 4 factors. The number of factors in excess returns remains relatively stable, whereas for turnover, it varies between 3 and 6 . However, our main interest here is to derive measures of idiosyncratic volatility and not to provide a test of the hypothesis that there is the same number of factors in return and turnover in the duo-factor model.
} 
of idiosyncratic risk in stock returns and trading volume, further confirming our previous results.

Cremers and Mei (2002) report a close relationship between idiosyncratic volatility and idiosyncratic turnover, based on the rationale that idiosyncratic volatility tends to be driven by firm-specific information on firm cash flows and risk, which also drives firm-specific trading volume. To the extent that Japanese idiosyncratic turnover displays a similar reduction during the crash period, our results showing a surprising decrease in firm-level volatility during the same time period are further strengthened.

In summary, by examining the Japanese stock market over three periods (prebubble, bubble and post-crash), we have documented different levels of total and idiosyncratic volatility over time. Total volatility increased after the collapse of the bubble, but, at the same time, idiosyncratic components significantly decreased. This stands in sharp contrast with the post-1962 U.S. market where market-level volatility does not show significant change over time, although firm-level volatility increases over time, especially during recessions (Campbell, Lettau, Malkiel, and Xu (2001)).

\section{Why Did Idiosyncratic Volatility Fall after 1990?}

We have so far documented increased market-wide volatility and decreased firmlevel volatility in Japan. In this section, we relate these findings to the economic environment of Japan, and particularly to some institutional factors that may be driving these phenomena.

A: An Introduction to "Japanese-Style" Capitalism 
The post-WWII Japanese economic system was centered on a "main bank" system in which major banks played an important, and quasi-public-sector role in supplying much needed capital for building the economy after the devastation and destruction of the war. Thus, major banks were at the core of all Japanese industrial groups (keiretsu). Main banks not only made loans to the keiretsu group, but also owned up to $10 \%$ (5\% after 1977$)$ of client firms (many of them in the keiretsu group).

Furthermore, main banks often sent directors to borrowing firms, especially when they were experiencing financial difficulties, and the monitoring capability of banks was believed to be effective (Aoki, Patrick, and Sheard, 1994). Main banks also provided much-needed liquidity for financially distressed firms, thus reducing the cost of financial distress (Hoshi, Kashyap, and Scharfstein, 1990). In addition, since bankruptcy procedures in Japan were quite time-consuming and expensive, and once filed, conferred immediate control to court-appointed trustees, managers had a strong incentive not to resort to them. As a result, as shown later, there were very few cases of bankruptcies of large, publicly traded firms in Japan.

While the Japanese model appeared to function well through the high-growth period, one can argue that it was not able to meet the challenges of the changing environment in the 1990s. Instead, the system created an excuse for staying with the status quo rather than implementing timely reforms. After the collapse of the bubble, many corporations faced problems, such as high leverage resulting from overly optimistic expansion plans during the bubble period, decreased collateral value owing to the decline in land values, and decline in revenues due to economic slowdown. However, corporate managers did not address these issues quickly. It is possible that their previous strong 
ties with main banks led them to believe that negotiated financial support, rather than legal bankruptcy procedures, would be possible and desirable. ${ }^{8}$

Financial regulators were also slow to reveal the problem of non-performing loans. Rather than facing the issue, they chose to use "easy" criteria for classifying nonperforming loans in their published statistics, delaying immediate and necessary reforms. Since banks were not directly writing off the non-performing loans, troubled borrowers were not forced to go bankrupt. Even firms widely recognized to be in serious financial distress for more than five years (e.g., large construction companies and some retail concerns) are still receiving support from banks. The practice of lifetime employment in large corporations is another element that has made it difficult for the skilled labor force to move from inefficient to more productive sectors.

\section{B. The Relationship between Bankruptcy and Idiosyncratic Risk}

Protection among keiretsu and main bank affiliated firms and the lack of reform in Japan's corporate sector may have led to a lack of "creative destruction" in the Japanese economy. Figures $4 \mathrm{a}$ and $4 \mathrm{~b}$ compare bankruptcies of all firms in the economy and those of the Tokyo Stock Exchange listed firms. ${ }^{9}$ As the figures reveal, the number of bankruptcies for firms listed on the Tokyo Stock Exchange is much smaller than the number for the entire economy. Among the former, there were only one to three bankruptcies per year from 1975 to 1996 , with the exception of 1984 when there were

\footnotetext{
${ }^{8}$ Nissan Motor, for example, asked for help from its main bank (Industrial Bank of Japan) over several years until at the end, in 1999, the French automaker Renault bought a substantial share of Nissan and sent a CEO to initiate a drastic restructuring. At the time of this transaction, analysts widely agreed that Nissan was actually insolvent.

${ }^{9}$ For the economy as a whole, the number of bankruptcies increased gradually from 1975 to 1984 , but decreased during the "bubble" boom period (1985-1990). The number started to increase again after the collapse of the bubble.
} 
five bankruptcies. In many years there were no bankruptcies at all. Indeed, from 1987 to 1991 (from the boom period to the beginning of the declining period), for five consecutive years, there were no bankruptcies. This low bankruptcy phenomenon continued until 1996, well into the period of economic downturn. It was only after 1997 that the number of bankruptcies started to increase, but even then the number remained below 10 per year. This is in sharp contrast with the U.S., where in 2000 (2001), there were 176 (257) bankruptcy filings of publicly traded companies. ${ }^{10}$ Bankruptcies of listed firms in Japan are particularly low since such firms are considered to have social and economic importance, and all parties involved (banks, other businesses, and regulators) deem them to be "too large to fail."

[Insert Figure 4a,b approximately here]

The Japanese stock market mirrored this period of procrastination. Since immediate restructuring of corporations and banks was not forthcoming, investors may have come to expect a prolonged period of corporate "bailouts and rescues" where cash flows from good firms are diverted to save weak firms in the same business group and to converge economic risk. Thus, we should observe a convergence of stock market returns and a reduction in firm-level volatility. This implies a positive relation between number of bankruptcies and idiosyncratic risk, and a negative relation between number of bankruptcies and market co-movement.

[Insert Table 5 approximately here]

To confirm the above hypothesis, we regress changes in firm-level volatility on the number of corporate bankruptcies of TSE listed firms and the annual growth rate of GDP. We use annual data for this regression and report the results in Table 5. Changes

\footnotetext{
${ }^{10}$ See http://www.bankruptcydata.com/
} 
in annual aggregate idiosyncratic risk are computed as changes in the 12-month average of the cross-sectional mean of idiosyncratic volatility obtained from the market model. For the full sample period, we find a weak positive relation between changes in firmlevel volatility and corporate bankruptcies; the higher number of bankruptcies is related to higher idiosyncratic volatility. We also regress changes in average $\mathrm{R}^{2}$ and average pair-wise correlations on the number of corporate bankruptcies of TSE firms and GDP growth. Generally we find a negative relation between number of bankruptcies and changes in average $\mathrm{R}^{2}$ and average pair-wise correlations. However, the relation between average $\mathrm{R}^{2}$ and GDP growth is mixed. ${ }^{11}$

\section{C: The Impact of Business Group Affiliation on Idiosyncratic Risk}

We have argued that a lack of creative destruction (bankruptcies) may have caused Japanese firm-level volatility to decrease during the 1990s. We now turn our attention to differences in the behavior of idiosyncratic volatility of keiretsu and nonkeiretsu firms, and firms with and without main banks. Our purpose is to examine whether these unique Japanese institutional features play a role in determining the firmlevel components of volatility and volume.

We first divide our sample into firms that belong to the six major keiretsu groups (Fuji, Mitsui, Mitsubishi, Daiichi-Kangyo, Sumitomo, and Sanwa), and firms that do not. We also divide the sample into firms that have a main bank affiliation and firms that do not. The classification is based on 1998 data in Kigyo Keiretsu Soran (1999), published by Toyo Keizai Shinpo Sha. We compute individual idiosyncratic components of return

\footnotetext{
${ }^{11}$ We also run these regressions for the 1990-1999 sub-period. The coefficients show a pattern consistent with the full sample. These results are available upon request.
} 
volatility and volume of these firms, and average them across firms within each category (keiretsu firms and non-keiretsu firms; and firms with main banks and firms without main banks) to obtain aggregate idiosyncratic components. ${ }^{12}$ We then regress the difference in aggregate idiosyncratic components between non-keiretsu firms and keiretsu firms on the monthly growth rate of industrial production (IP). We include an intercept to control for the difference in idiosyncratic components due to differences in industrial composition.

Table 6 reports regression results for the difference in idiosyncratic components of return volatility and volume between non-keiretsu firms and keiretsu firms (Panel A), and between firms with main banks and firms without main banks (Panel B). We report results for before the collapse of the bubble (high- and medium-economic growth periods), and the post-bubble (low-growth period). Noting that there is a reversal in the pattern of idiosyncratic risk around 1997, we report results for the 1990-1996 period.

The results for the 1977-1989 period in Panel A show a generally positive relation between IP growth and the difference in idiosyncratic components; an increase in IP growth tends to increase the difference of firm-level volatility between non-keiretsu and keiretsu firms. A higher growth rate of the IP implies higher firm-level volatility and volume of non-keiretsu firms compared to keiretsu firms. This means that, in this subperiod, when economic growth is at a high rate, there tends to be greater disparity of stock performance among non-keiretsu firms. Less disparity among the performance of stocks of keiretsu firms during the high-growth period implies the presence of resource sharing among these firms, whereas independent firms who do not share resources experience a higher degree of disparity in volatility. Panel B shows that the same results

\footnotetext{
${ }^{12}$ We have also used other single- and multi-factor models to compute idiosyncratic components. The results are quite similar and available upon request from the authors.
} 
hold for firms without main banks versus firms with main banks, and all coefficients are significant.

When we run the same regressions for the 1990-1996 (post-crash period), the sign of the coefficients flips to negative, and they are all significant except for one case. In this sub-period, a decrease in IP growth tends to increase the difference of firm-level components between non-keiretsu and keiretsu firms (Panel A) and between firms without main banks and firms with main banks (Panel B). The lower the IP growth, the higher the firm-level components of non-keiretsu firms (firms without main banks) compared to keiretsu firms (firms with main banks). This means that in this sub-period when the rate of economic growth is low, there tends to be greater disparity of stock performance among non-keiretsu firms and firms without main banks, compared to their counterparts. These findings suggest that keiretsu firms and firms with main banks are less sensitive to negative economic conditions compared to independent firms.

\section{D: Increasing Homogeneity of Economic Performance among Japanese Firms}

While the above study has documented a falling firm-level volatility in Japanese stock returns, one may wonder if this phenomenon is driven by the underlying fundamentals of firm performance. To address this question, Figures $5 \mathrm{a}$ and $5 \mathrm{~b}$ report the average 10-year pair-wise return on asset (ROA) correlations and cross-sectional standard deviation of ROAs over the sample period. ${ }^{13}$ Since Japanese corporations report earnings on an annual basis, we are limited to annual ROA figures. The most striking result shown in Figure 5a is the $300 \%$ increase (from 0.05 to 0.23 ) in the average 10 -year ROA correlations for all firms in the economy. This suggests that in the 1990s, the fortunes of

\footnotetext{
${ }^{13}$ We use ROA rather than return on equity (ROE) since leverage may differ across firms.
} 
Japanese firms were tied together very tightly and their fundamental economic performance moved much more in lock step as compared to the pre-crash period. Since stock returns are related to firm performance through earnings and dividends, the dramatic rise in ROA correlations appears to be an important driver to rising return correlations and falling idiosyncratic volatility.

Another interesting fact revealed in Figure 5a is that group affiliated firms (keiretsu and main bank (MB)) have higher ROA correlations in the post-bubble period, suggesting that the fundamental performances of group firms were also more closely tied together during this period. From Figure 5b, which presents the standard deviations of ROA for both non-keiretsu and keiretsu firms, we can observe that the standard deviations of ROA for non-keiretsu firms tend to be higher than those of keiretsu firms. ${ }^{14}$ Thus, there is less variation of firm performance among keiretsu firms.

\section{[Insert Figure 5a and 5b approximately here]}

As shown in Figures 2 and 3, firm-level volatility increased after 1997. Although the small number of observations does not allow us to conduct a statistical test, it appears that the increase in firm-level volatility is related to the recent increase in bankruptcies and discussions in the Japanese parliament on the adoption of a new bankruptcy law. ${ }^{15}$

As we can see from Figure 5, the standard deviation of ROA had the largest jump for keiretsu firms after 1997, when several large banks and firms were allowed to fail. Moreover, there is some anecdotal evidence that the market actually looks forward to

\footnotetext{
${ }^{14}$ We have also performed the same analysis on the ROAs of firms with and without main banks affiliations. The results, however, are mixed for the whole sample period.

${ }^{15}$ In April 2000, another bankruptcy procedure under a new law (minji-saisei-hou) was introduced. This procedure requires fewer legal steps, and once bankruptcy is filed, managers can stay during the restructuring. Although the number of filings is still low, there were six (seven) cases out of ten (nine) bankruptcies in 2000 (2001). This may contribute to the future improvement of information efficiency measures in the Japanese market.
} 
bankruptcy filing of failing firms, rather than prolonged rescue negotiation involving their main banks. ${ }^{16}$ On the other hand, when Daiei, a large retail chain, and its banks agreed on a rescue plan including a 400 trillion yen debt-equity swap on January 15 , 2002, the Nikkei average went down by $1 \%$ and "the rumor (of the rescue) pushed down bank stocks by $7 \%$ over the previous week." 17

\section{The Impact of Financial Markets on Economic Activity}

\section{A. A Possible Vicious Cycle in the Capital Formation Process}

The above analysis has demonstrated that a lack of corporate bankruptcy and the presence of group protection may have contributed to an increase in Japanese equity comovement. The role of equity markets, however, is not just a passive reflection of the Japanese economy.

Numerous theoretical and empirical studies have demonstrated that equity markets help improve the capital allocation process, and thus contribute to economic growth. One theory is that efficient secondary market prices help investors separate good from bad investments through a mechanism like Tobin's Q. Another is that lenders and intermediaries use book-to-market ratios to screen out bad credits (Altman, 2002). Agency theories argue that pressure from external investors, or managerial ownership, encourages managers to pursue value-maximizing investment policies (Jensen, 1986). ${ }^{18}$

\footnotetext{
${ }^{16}$ For example, when Mycal, a large supermarket chain, filed for minji-saisei-hou bankruptcy on September 17, 2001, with 74 trillion yen in debt, the Nikkei average went $u p$ by $4 \%$ because of "the expectation in the market that the disposition of bad debts by banks would accelerate (Nihon Keizai Shinbun (Japan Economic Journal), September 17, 2001). A similar market reaction was observed when a construction company, Sato Kogyo, filed for bankruptcy on March 4, 2002, with a total debt amount of 560 trillion yen, and the Nikkei average went up by $5 \%$.

${ }^{17}$ Nihon Keizai Shinbun (Japan Economic Journal), January 15, 2002.

${ }^{18}$ La Porta, Lopez-de-Silanes, Shleifer, and Vishny (1997) show that effective laws against misuse of minority investors' funds are a key determinant of their supply of finance to good projects.
} 
Recent empirical work by Wurgler (2000) demonstrates that equity markets actually do improve the allocation of capital. Using a sample of 65 countries, he shows that countries with stock markets that impound more firm-specific information into individual stock prices - in other words, those that have a smaller $\mathrm{R}^{2}-$ do exhibit a better allocation of capital, ..."which appears to be particularly useful for limiting investment in declining industries." Durnev, Morck, and Yeung (2001) also find that firms in industries in which firm-specific return variation is larger exhibit a higher quality of capital budgeting, in the sense that their profitability indices (marginal Q ratios) are closer to one.

These results suggest that equity markets play an active role in the allocation of capital itself. While misallocation of capital by major banks and keiretsu may cause an increase in Japanese equity co-movement, this in turn could lead to further misallocation of capital by firms and investors. As discussed in section III, large equity price comovement makes it difficult for investors to distinguish good from bad firms. As a result, some healthy firms will find it difficult to get financing and stay competitive. This in turn will lead to more "rescues and bailouts" by business groups, which will trigger further reductions in firm-level volatility, thus leading to a vicious cycle in the capital formation process.

We conjecture that this vicious cycle of capital misallocation may help explain the long stagnation of the Japanese economy. Fundamentally, the strength of an economy can be measured by whether it allocates its scarce capital efficiently. Capital should be invested in firms that are expected to have high returns, and withdrawn from firms with poorer prospects. To the extent that the Japanese economy continues to misallocate large amounts of scarce capital, its recovery will remain illusive, despite its large capital 
endowment. While Japanese corporations and government recently have taken steps to address the issue of corporate reorganization, these results indicate that firm-level volatility in Japan is still too low (and $\mathrm{R}^{2}$ is too high) compared to other developed countries, indicating that Japan's corporate restructuring may still have a long way to go. ${ }^{19}$

\section{B. Comparison with the U.S. Market in the Pre-War Period}

In the aftermath of the 1929 crash, the U.S. experienced one of the most severe and prolonged recessions in its history. Thousands of banks failed, one quarter of its labor force was unemployed, and the economy did not return to its pre-crash peak until World War II. While the recent Japanese recessions are much more moderate compared to the U.S. experience, they have nonetheless lasted on and off for over 10 years. An interesting question is: what are the similarities between the world's two most prolonged recessions?

\section{[Insert Figure 6a,b approximately here]}

To answer this question, we have computed monthly market volatility and idiosyncratic volatility from monthly returns of individual stocks using U.S. data from 1928 to 1946, following the same methodology as in Xu and Malkiel (2001). We have also computed average pair-wise correlation and $\mathrm{R}^{2}$. The results are presented in Figures $6 \mathrm{a}$ and $6 \mathrm{~b}$. The periods between the two vertical lines are recessions.

While there are some distinctive features of each market, there is a striking similarity between the average $\mathrm{R}^{2} \mathrm{~s}$ (and average pair-wise correlations) of the post-1990

\footnotetext{
${ }^{19}$ At the end of 1999 , the average $\mathrm{R}^{2}$ of the Japanese market was 0.25 , still much higher than that of the U.S. (about 0.08 over the 1993-1998 period) and its own pre-crash historical level.
} 
Japanese equity market and the post-1929 U.S. equity market. We observe a large increase in the average $\mathrm{R}^{2} \mathrm{~s}$ for both markets. While it is reasonable to expect average $\mathrm{R}^{2}$ to increase during a market crash, it is noteworthy that the average $\mathrm{R}^{2} \mathrm{~s}$ for both countries stayed at high levels for such a long period of time. The average $\mathrm{R}^{2}$ for returns in Japan exceeded 30\% between 1992 and 1999. The average $\mathrm{R}^{2}$ for returns in the U.S. exceeded 40\% between 1930 and 1935 and remained above that level between 1937 and 1941.

There is no doubt that the underlying economic factors driving the large increases in average $\mathrm{R}^{2}$ are different in the two countries. As we can clearly see from Figure 6a and $6 \mathrm{~b}$, the rising average $\mathrm{R}^{2}$ in the U.S. is accompanied by a dramatic rise in overall market volatility, possibly due to widespread bank failures and corporate bankruptcies. ${ }^{20}$ In comparison, the rising average $\mathrm{R}^{2}$ in Japan is accompanied by rapidly falling firmlevel volatility, possibly due to corporate "bailouts" and lack of reorganization. In both cases, high market volatility could affect capital investment by increasing the cost of capital. While the increase in market volatility is less dramatic in Japan than it was in the U.S. in the 1930s, the accompanying sharp fall in firm-level volatility made it equally difficult for Japanese investors to separate high quality from low quality firms. This may have had a further adverse impact on the capital formation process and thus worsened the overall economic conditions.

\section{Conclusion}

This paper documents an abnormal reduction in firm-level volatility after the Japanese stock market crash. We find a significant drop in the variation of systematic risk across firms and a sharp increase in Japanese equity co-movement. In order to

\footnotetext{
${ }^{20}$ See Bernanke (1981) on the possible cause of U.S. depression.
} 
understand the abnormal behavior of idiosyncratic risk in Japan, we examine the impact of firm fundamentals as well as bankruptcy on firm-level volatility. We find that firm fortunes were tied together very tightly during the post-crash period. We discover a positive correlation between changes in aggregate firm-level volatility and corporate bankruptcies. There is some circumstantial evidence that increasing bankruptcies after 1997 have led to higher firm-level volatility. In addition, we find that idiosyncratic volatility for firms with business group affiliations is less responsive to economic conditions than that of firms without such affiliations. These results suggest that the sharp fall in firm-level volatility could be due to group protection.

Based on these results, we hypothesize that the lack of "creative destruction" may have contributed to an increase in Japanese equity co-movement and added to the difficulty of sorting out healthy firms in the capital allocation process. Interestingly, we find that the volatility behavior of Japanese equities resembles that of U.S. equities during the Great Depression, both of which show a prolonged large co-movement in equity prices. In both cases, there seem to be deficiencies in the capital formation process, which may have contributed to the worsening of the overall economic conditions.

To obtain a more accurate measure of idiosyncratic risk, this paper has made a number of methodological innovations. First, we have introduced volume into our asset pricing studies. Because of the close relationship between idiosyncratic risk and idiosyncratic volume, examining the time-variation of idiosyncratic volume allows us to better understand firm-level volatility in the Japanese equity market. Second, as a robustness check, we employ the duo-factor model of Lo and Wang (2000), which 
provides an alternative measure of firm-level volatility and trading volume in a multifactor setting. Third, we use a recently developed consistent statistic by Xu (2001) to determine the number of factors in the duo-factor model. This could provide a more accurate measure of idiosyncratic volatility in a multifactor model.

This paper raises many interesting research questions. First, while our results indicate an increase in Japanese equity co-movement and a potential negative impact on its capital allocation, it would be interesting to examine whether this increase actually leads to reduced efficiency in Japanese firm capital budgeting. Second, our results indicate that a reduction in idiosyncratic volatility is accompanied by rising overall market volatility in Japan. It would be useful to examine whether changes in idiosyncratic risk have affected asset pricing. ${ }^{21}$ We leave these topics for future research.

\footnotetext{
${ }^{21}$ Goyal and Santa-Clara (2002), for example, have examined the issue of whether idiosyncratic risk has affected asset pricing in the U.S.
} 


\section{Appendix}

Let us briefly introduce the framework we adopt from Lo and Wang (2000). Assume that asset i returns are generated by an approximate $K$-factor model:

$$
R_{i t}=E_{t}\left(R_{i t}\right)+f_{1 t} \beta_{i 1}+\ldots+f_{K t} \beta_{i K}+e_{i t} \quad i=1, \ldots, N ; \quad t=1, \ldots, T,
$$

where $f_{t}{ }^{\prime}=\left(f_{1 t}, \ldots, f_{K}\right)$ is a vector of unobservable pervasive shocks, $\left(\beta_{i 1}, \ldots, \beta_{i K}\right)$ is a vector of factor loadings which are constant over the sample period, and $e_{i t}$ represents an idiosyncratic risk specific to asset $j$ at time $t$. As discussed in Chamberlain (1983), the above economy implies the following linear pricing relationship if there exist $\mathrm{K}$ welldiversified portfolios:

$$
E_{t}\left(R_{i t}\right)=r_{f t}+\lambda_{1 t} \beta_{i 1}+\ldots+\lambda_{K t} \beta_{i K}
$$

where $\left(\lambda_{1}, \ldots, \lambda_{K t}\right)$ is a vector of risk premiums corresponding to the pervasive shocks $\left(f_{1}, \ldots, f_{K t}\right)$, and $r_{f t}$ is the return on a riskless asset.

Parallel to Equation (A1), Lo and Wang (2000) derive the proposition that the turnover of each stock also has an approximate K'-factor structure under certain regularity conditions. More formally, we have:

$$
\tau_{i t}=\tau_{i}+\delta_{i 1} g_{1 t}+\ldots+\delta_{i K} g_{K^{\prime} t}+\xi_{i t}
$$

Here, $\delta_{i k}$ is the exposure of firm i to economy-wide liquidity shocks $g_{k t} \cdot \mathrm{g}_{k t}$ could be functions of $\mathrm{f}_{k t}$ but it is not specified in the model and $\tau_{i}$ is a constant. $\xi_{i t}$ has mean zero and it is assumed to be orthogonal to $g_{k t}$. Since the models of (A1) and (A3) are both multi-factor models, we will simply call them the duo-factor model for return and volume. Our objective here is to use (A1) and (A3) to derive alternative measures of idiosyncratic volatility and turnover. 
An important issue in measuring idiosyncratic volatility and turnover is the correct identification of the number of factors in (A1) and (A3). Until now, this crucial parameter is often assumed, rather than determined by the data. ${ }^{22}$ This paper introduces a formal statistical procedure that can consistently estimate the number of factors from observed data. This procedure is developed by Xu (2001) under the assumption that both $\mathrm{N}$ and $\mathrm{T}$ converge to infinity. This extension is of empirical relevance because it fully exploits the advantage of a large panel data set. In addition, our empirical study employs an approximate factor structure for both returns and trading volume. Our results hold under heteroskedasticity in both the time and cross-section dimensions, thus rendering them more general than the results of Connor and Korajczyk (1993) who assume homoskedasticity over time.

\footnotetext{
${ }^{22}$ Brown and Weinstein (1983) emphasize the importance of obtaining correct estimates on the number of factors. They point out that the common practice of using an over-estimate can cause spurious rejection of asset pricing models. They note: "...the rejection of the five and seven factor versions is to be expected if the three factor version is correct."
} 


\section{References}

Altman, E., 2002, "Recent Advances in Corporate Finance; Investing in Junk Bonds; Default Risk, Mortality Rates," John Wiley Frontiers in Finance Series.

Aoki, M., H. Patrick, and P. Sheard, 1994, "The Japanese Main Bank System: An Introductory Overview," in Aoki, M., and H. Patrick (eds), The Japanese Main Bank System: Its Relevance for Developing and Transforming Economies, Oxford: Oxford University Press.

Beck, T., R. Levine, and N. Loayza, 1999, "Finance and the Sources of Growth," Working Paper, University of Virginia.

Bernanke, B., 1981, Bankruptcy, Liquidity, and Recession, American Economic Review, 71, 155-159.

Caballero, R. J., and M. Hammour, 1994, "The Cleansing Effect of Recessions," American Economic Review 84, 1350-1368.

Campbell, J.Y., M. Lettau, B.G. Malkiel, and Y. Xu, 2001, "Have Individual Stocks Become More Volatile? An Empirical Exploration of Idiosyncratic Risk," Journal of Finance, 56, 1:43.

Chamberlain, G., 1983, "Funds, Factors, and Diversification in Arbitrage Pricing Models,” Econometrica, 51, 1305-1323.

Chan L., Y. Hamao, and J. Lakonishok, 1991, "Fundamentals and Stock Returns in Japan," Journal of Finance, 46, 1739-1764.

Connor, G. and R. Korajczyk, 1993, "A Test for the Number of Factors in an Approximate Factor Model," Journal of Finance, 48, 1263-1291.

Cremers, M., and J. Mei, 2002, “A New Approach to the Duo-Factor-Model of Return and Volume," Working Paper, New York University.

Daniel, K., S. Titman, and K.C.J. Wei, 2001, "Explaining the Cross-Section of Stock Returns in Japan," Journal of Finance, 56, 743-756.

Demirguc-Kunt, A., and V. Maksimovic, 1998, "Law, Finance, and Firm Growth," Journal of Finance, 53, 2107-2137.

Durnev, A., R. Morck, and B. Yeung, 2001, "Dr. Jekyll and Mr. Hyde: Stock Return Variation and the Quality of Capital Budgeting Decision," Working Paper, New York University. 
Durnev, A., R. Morck, B. Yeung, and P. Zarowin, 2002, "Does Greater Firm-Specific Return Variation Mean More or Less Informed Stock Trading?” Working Paper, New York University.

Eden, B., and B. Jovanovic, 1994, "Asymmetric Information and the Excess Volatility of Stock Prices," Economic Inquiry, 32, 228-235.

Fama, F. and K. French, 1993, "Common Risk Factors in the Returns on Stocks and Bonds," Journal of Financial Economics, 33, 3-56.

Foster, D. P., and D. B. Nelson, 1996, "Continuous Record Asymptotics for Rolling Sample Variance Estimators," Econometrica, 64, 139-174.

Goyal, A. and P. Santa-Clara, 2002, “Idiosyncratic Risk Matters!” Working Paper, University of California, Los Angeles.

Hamao, Y., 1991, "A Standard Data Base for the Analysis of Japanese Security Markets," Journal of Business, 64, 87-102.

Hoshi, T., A. Kashyap, and D. Scharfstein, 1990, "The Role of Banks in Reducing the Costs of Financial Distress in Japan," Journal of Financial Economics, 27, 67-88.

Jayaratne, J., and P. E. Strahan, 1996, "The Finance-Growth Nexus: Evidence from Bank Branch Deregulation," Quarterly Journal of Economics, 111, 639-670.

Jensen, M., 1986, “Agency Costs of Free Cash Flow, Corporate Finance and Takeovers," American Economic Review, 76, 323-329.

King, R. G., and R. Levine, 1993, "Finance and Growth: Schumpeter Might be Right," Quarterly Journal of Economics, 108, 717-737.

Krugman, P., 1999, The Return of Depression Economics, W.W. Norton Company.

La Porta, R., F. Lopez-de-Silanes, A. Shleifer, and R. W. Vishny, 1997, "Legal Determinants of External Finance," Journal of Finance, 52, 1131-1150.

Levine, R., 1998, “The Legal Environment, Banks, and Long-Run Economic Growth," Journal of Money, Credit \& Banking, 30, 596-613.

Levine, R., and S. Zervos, 1998, "Stock Markets, Banks, and Economic Growth," American Economic Review, 88, 537-558.

Lo, A., and J. Wang, 2000, "Trading Volume: Definitions, Data Analysis, and Implications of Portfolio Theory," Review of Financial Studies, 13, 257-300.

Mei, J., 1993, "A Semi-Autoregression Approach to the Arbitrage Pricing Theory," Journal of Finance, 48, 599-620. 
Morck, R., B. Yeung, and W. Yu, 1999, "Why Do Emerging Markets Have Synchronous Stock Price Movements?” Working Paper, University of Alberta.

Roll, R. and S. Ross, 1980, “An Empirical Investigation of the APT," Journal of Finance, $35,1073-1103$.

Wurgler, J., 2000, "Financial Markets and the Allocation of Capital," Journal of Financial Economics, 58, 187-214.

Xu, Y., 2001, “Extracting Factors with Maximum Explanatory Power,” Working Paper, The University of Texas at Dallas.

Xu, Y., and B. Malkiel, 2001, "Investigating the Behavior of Idiosyncratic Volatility," Journal of Business, forthcoming. 
Table 1: Summary Statistics

This table shows some of the summary statistics for Japanese equity markets over different episodes. Except for " $R_{M}$ ", which is based on the value-weighted market index return, all the statistics are computed based on the statistics of individual stocks in the specified period. In particular, $\sigma_{\mathrm{i}, \mathrm{IV}}$ is the root mean squared residuals from the same CAPM that computes $\beta_{\mathrm{i}, \mathrm{CAPM}}$ and $R_{\text {CAPM. }}^{2} \sigma_{\mathrm{i}, \mathrm{TV}}$ is the return volatility of individual stocks. $\bar{\eta}_{i}$ denotes the average turnover over time of individual stocks, while $\log \left(\overline{\mathrm{ME}_{\mathrm{i}}}\right)$ is the average market capitalization for individual stocks.

\begin{tabular}{lcccccccc}
\hline & $R_{M}$ & $\overline{R_{i}}$ & $\beta_{\mathrm{i}, \mathrm{CAPM}}$ & $R_{\mathrm{CAPM}}^{2}$ & $\sigma_{\mathrm{i}, \mathrm{IV}}$ & $\sigma_{\mathrm{i}, \mathrm{TV}}$ & $\left.\log (\overline{\mathrm{ME}})_{\mathrm{i}}\right)$ & $\overline{\eta_{i}}$ \\
\hline Median & & & & $1975-79$ & & & & \\
Mean & 0.016 & 0.015 & 0.997 & 0.117 & 0.085 & 0.093 & 9.523 & 0.037 \\
S.D. & 0.033 & 0.010 & 0.599 & 0.132 & 0.090 & 0.096 & 9.586 & 0.050 \\
& & & & 0.095 & 0.036 & 0.037 & 1.422 & 0.049 \\
Median & & 0.012 & 0.951 & 0.086 & 0.081 & 0.085 & 9.919 & 0.027 \\
Mean & 0.013 & 0.014 & 0.996 & 0.103 & 0.087 & 0.091 & 10.010 & 0.040 \\
S.D. & 0.026 & 0.011 & 0.653 & 0.083 & 0.040 & 0.041 & 1.473 & 0.040 \\
& & & & $1985-89$ & & & & \\
Median & & 0.028 & 1.027 & 0.157 & 0.097 & 0.107 & 10.889 & 0.049 \\
Mean & 0.027 & 0.028 & 1.024 & 0.172 & 0.106 & 0.115 & 11.036 & 0.056 \\
S.D. & 0.041 & 0.012 & 0.447 & 0.113 & 0.039 & 0.038 & 1.440 & 0.039 \\
& & & & $1990-94$ & & & & \\
Median & & -0.004 & 1.016 & 0.538 & 0.076 & 0.116 & 11.147 & 0.022 \\
Mean & -0.004 & -0.004 & 1.011 & 0.513 & 0.080 & 0.117 & 11.270 & 0.027 \\
S.D. & 0.083 & 0.007 & 0.321 & 0.168 & 0.024 & 0.029 & 1.373 & 0.022 \\
& & & & $1995-99$ & & & & \\
Median & & -0.007 & 0.983 & 0.407 & 0.085 & 0.115 & 10.573 & 0.021 \\
Mean & -0.004 & -0.005 & 1.006 & 0.387 & 0.093 & 0.122 & 10.777 & 0.027 \\
S.D. & 0.075 & 0.012 & 0.519 & 0.188 & 0.039 & 0.049 & 1.507 & 0.024 \\
\hline
\end{tabular}


Table 2: Test of Significance for the Difference between 1990-1994 Period and Other

\section{Periods}

This table provides the significant test of selected statistics of 1990-1994 against other time periods. This comparison period has 1521 stocks. Test statistics for the hypothesis of equal standard deviation is computed based on an F test, while that of equal mean is based on a $t$ test. In particular, $\sigma_{\mathrm{i}, \mathrm{IV}}$ is the root mean squared residuals from the same CAPM that computes $\beta_{\mathrm{i}, \mathrm{CAPM}}$ and $R_{\text {CAPM }}^{2} \cdot \bar{\eta}_{i}$ denotes the average turnover over time of individual stocks.

\begin{tabular}{|c|c|c|c|c|c|c|c|}
\hline & No. & $\beta_{\mathrm{i}, \mathrm{CAPM}}$ & $R_{\mathrm{CAPM}}^{2}$ & $\sigma_{i, I V}$ & $\sigma_{\mathrm{i}, \mathrm{IV}}$ & $\overline{\eta_{i}}$ & $\overline{\eta_{i}}$ \\
\hline & Obs. & S.D. & Mean & Mean & S.D. & Mean & S.D. \\
\hline & & & & $1975-79$ & & & \\
\hline Statistic & 1174 & 3.268 & -69.56 & 8.498 & 2.165 & 16.28 & 5.171 \\
\hline P-value & & 0.000 & 0.000 & 0.000 & 0.000 & 0.000 & 0.000 \\
\hline & & & & $1980-84$ & & & \\
\hline Statistic & 1275 & 4.152 & -79.29 & 5.037 & 2.710 & 11.36 & 3.505 \\
\hline P-value & & 0.000 & 0.000 & 0.000 & 0.000 & 0.000 & 0.000 \\
\hline $\begin{array}{l}\text { Statistic } \\
\text { P-value }\end{array}$ & 1352 & $\begin{array}{l}1.942 \\
0.000\end{array}$ & $\begin{array}{c}-62.91 \\
0.000\end{array}$ & $\begin{array}{c}1985-89 \\
20.87 \\
0.000\end{array}$ & $\begin{array}{l}2.648 \\
0.000\end{array}$ & $\begin{array}{l}24.94 \\
0.000\end{array}$ & $\begin{array}{l}3.288 \\
0.000\end{array}$ \\
\hline $\begin{array}{l}\text { Statistic } \\
\text { P-value }\end{array}$ & 1606 & $\begin{array}{l}2.624 \\
0.000\end{array}$ & $\begin{array}{c}-19.71 \\
0.000\end{array}$ & $\begin{array}{c}1995-99 \\
10.86 \\
0.000\end{array}$ & $\begin{array}{l}2.668 \\
0.000\end{array}$ & $\begin{array}{r}-0.167 \\
0.566\end{array}$ & $\begin{array}{l}1.220 \\
0.000\end{array}$ \\
\hline
\end{tabular}




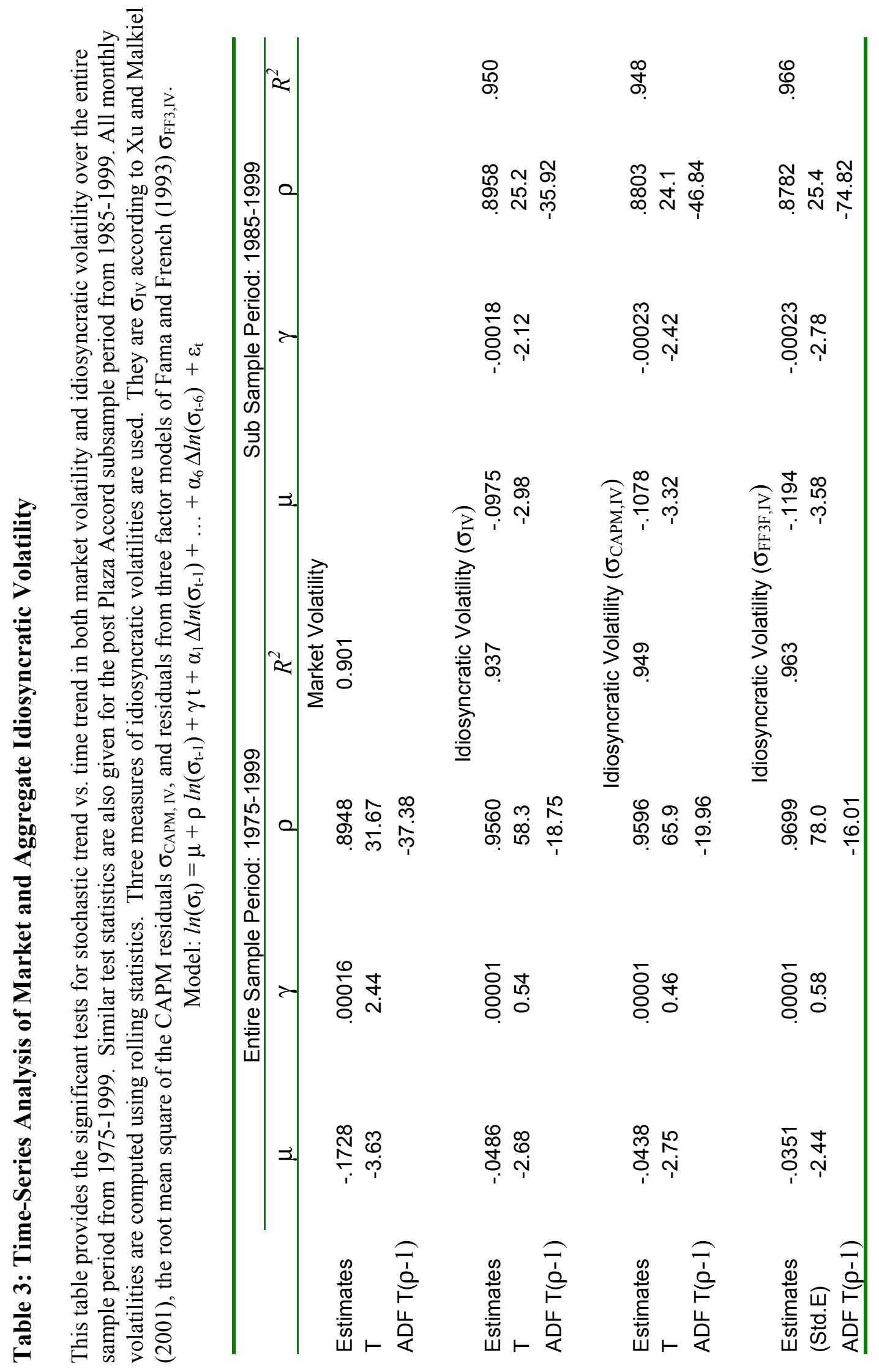




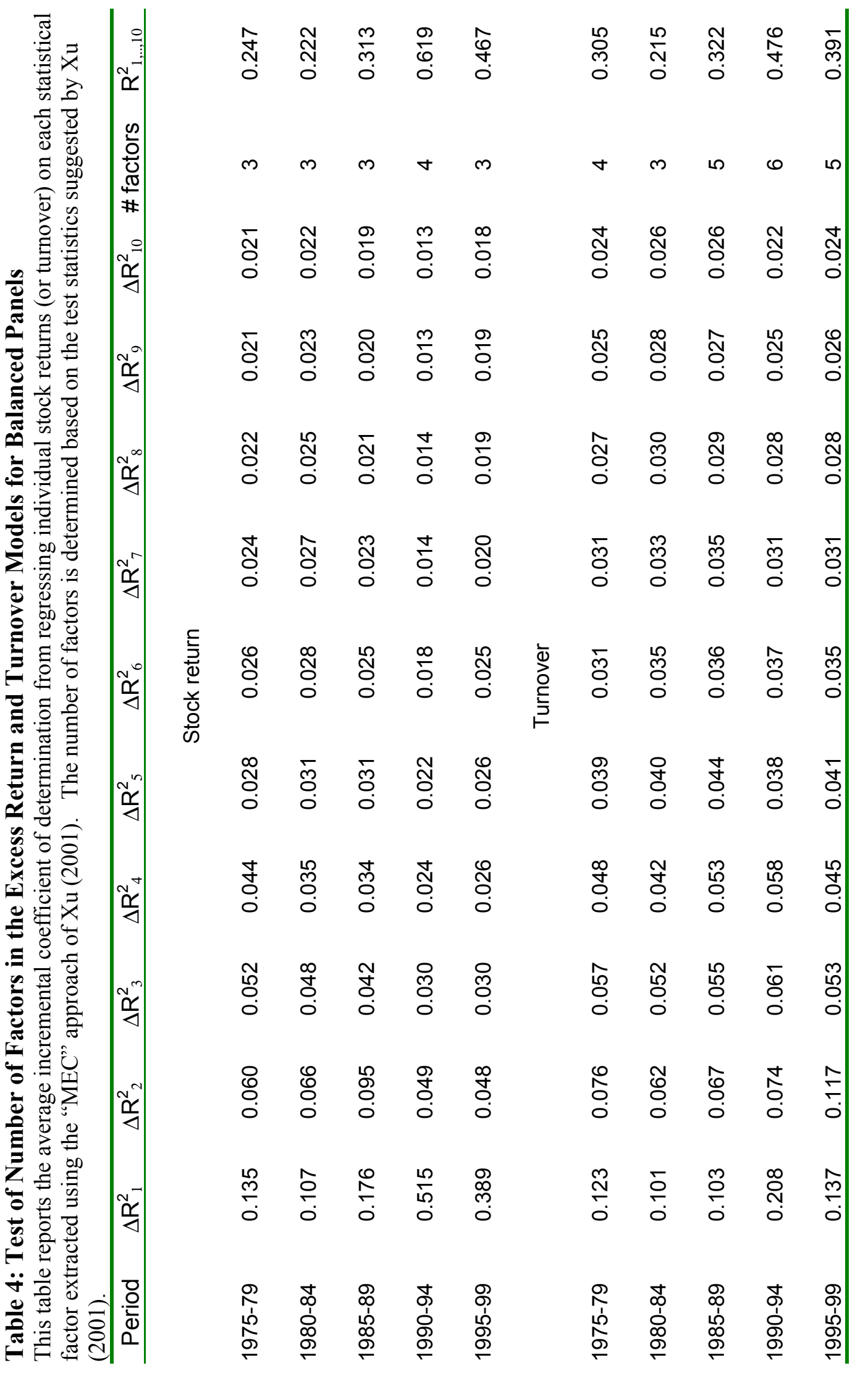




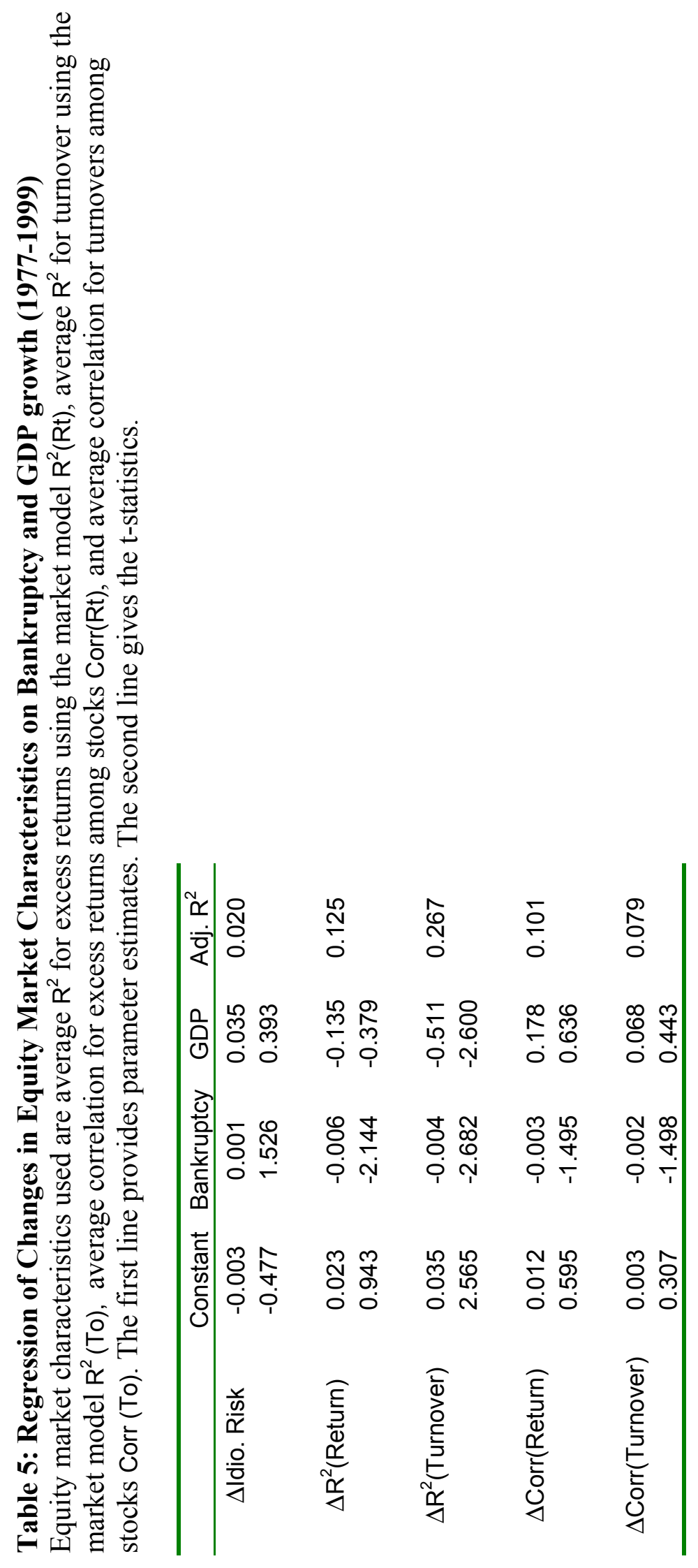




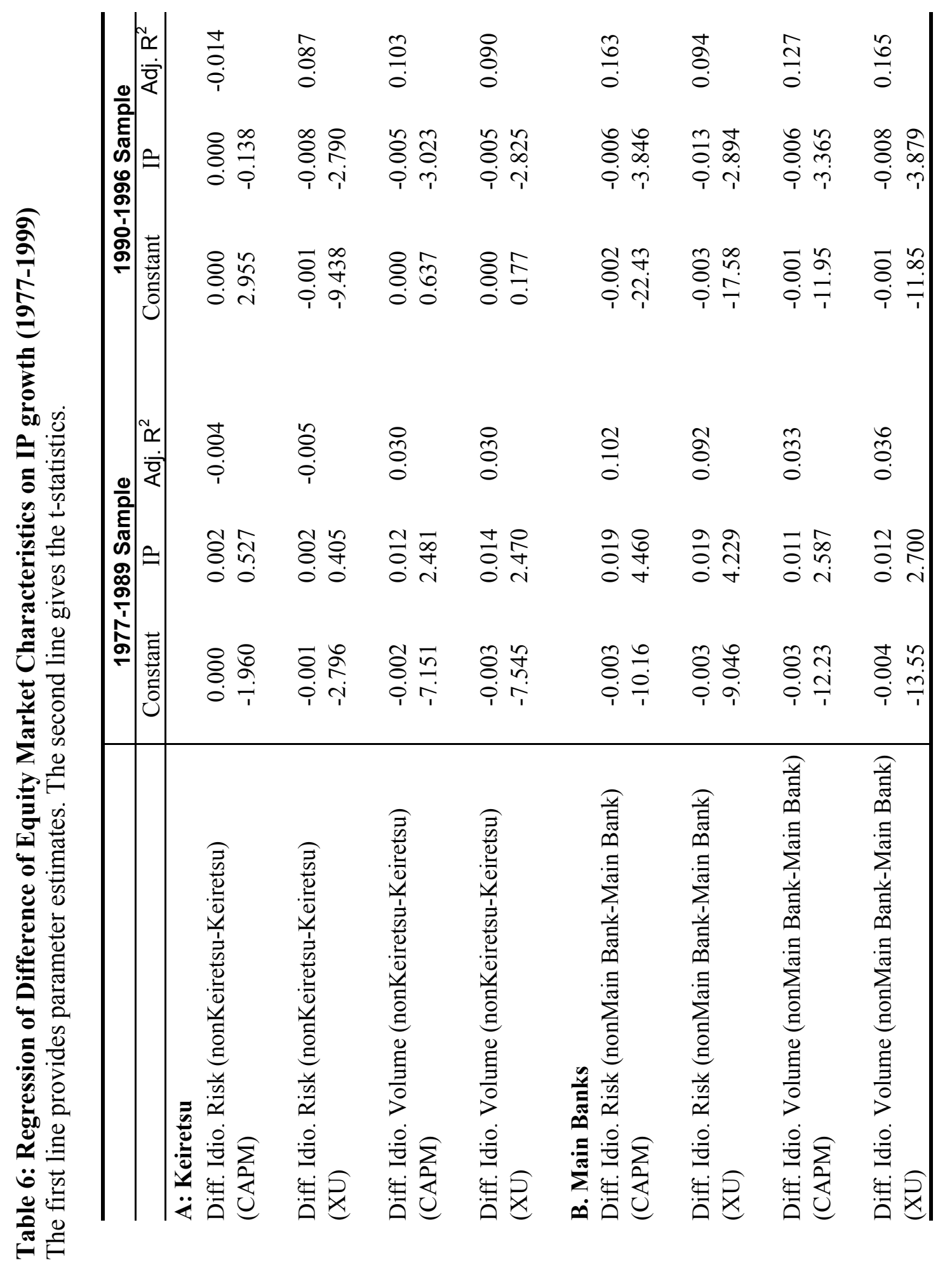




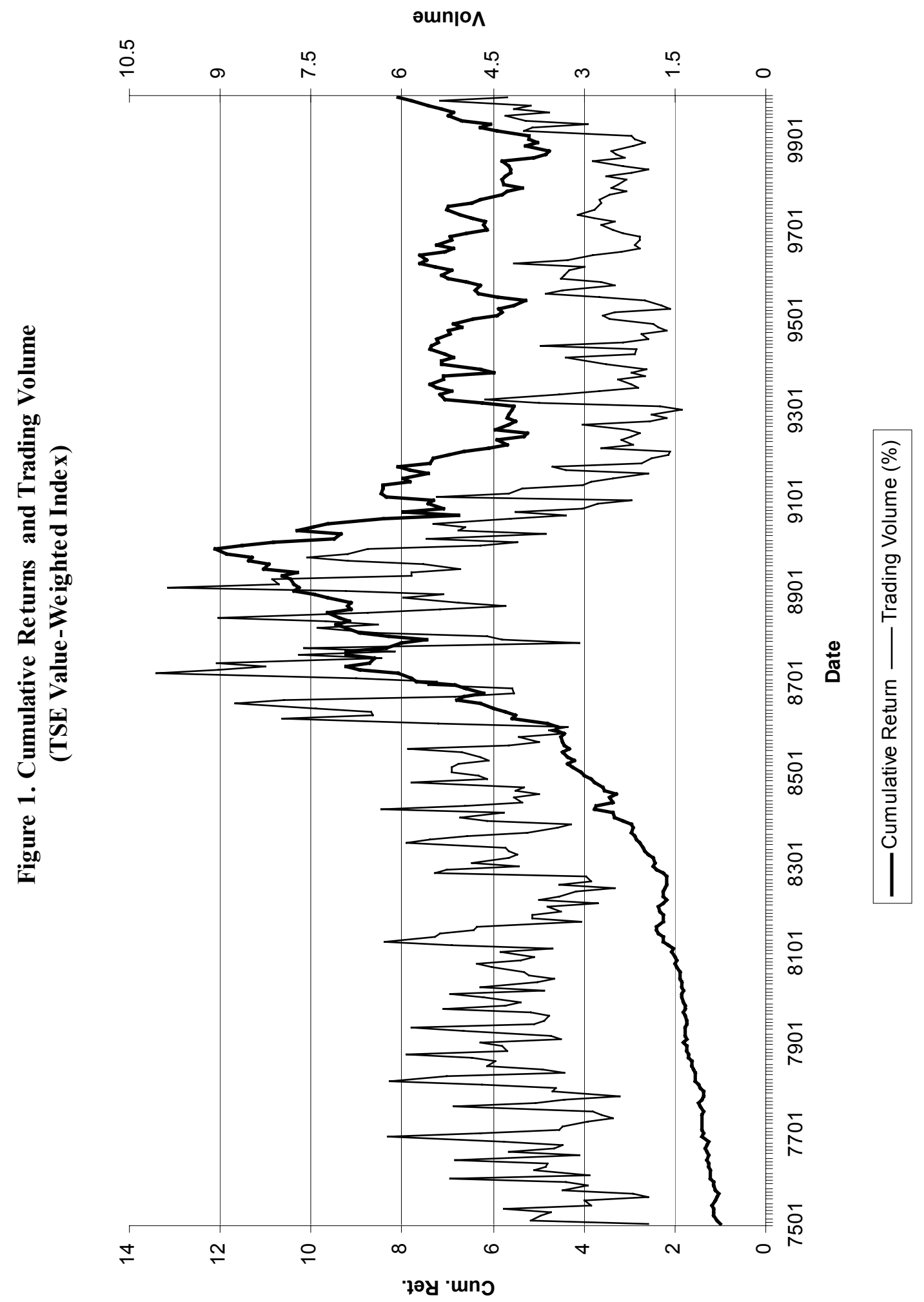




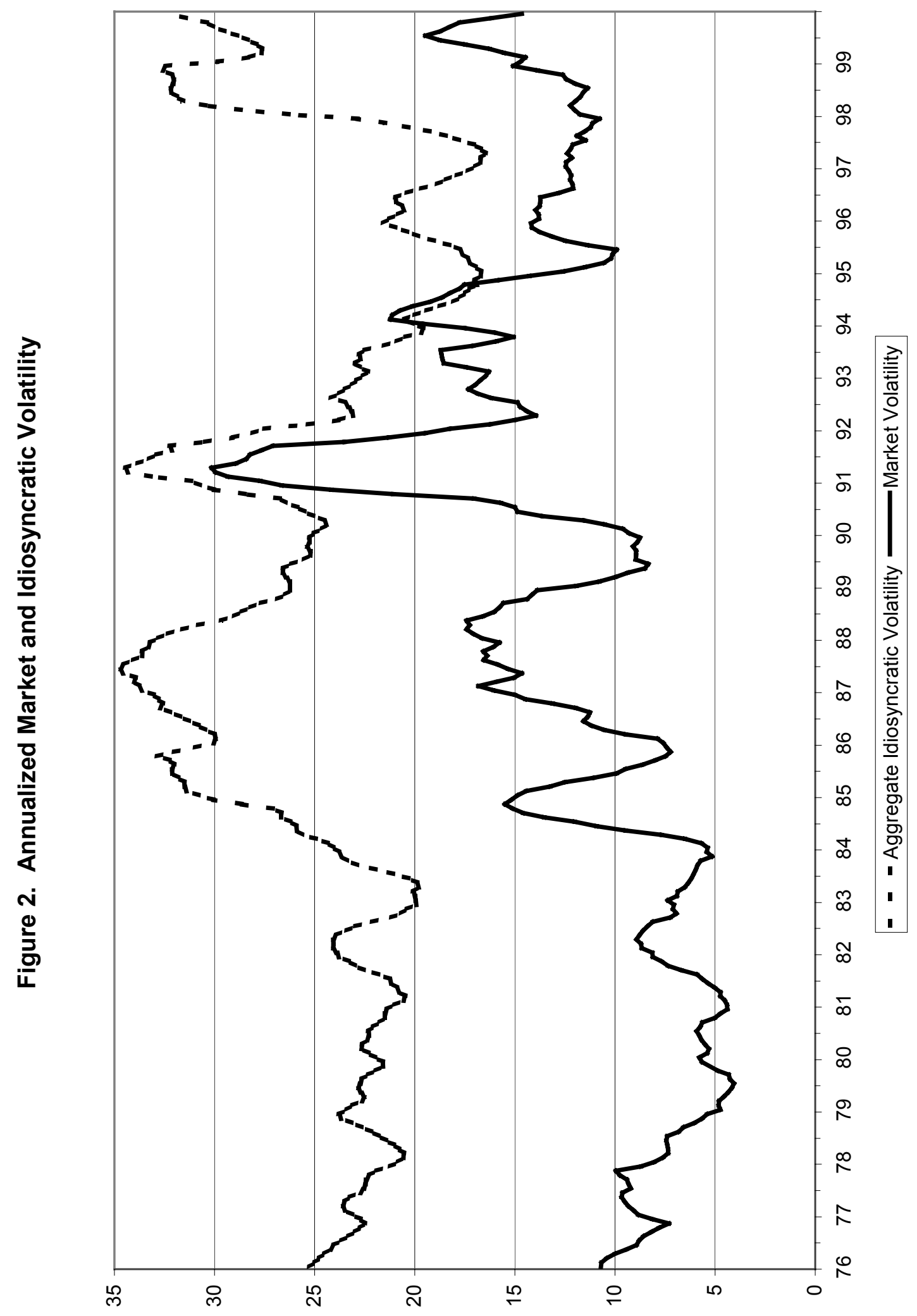




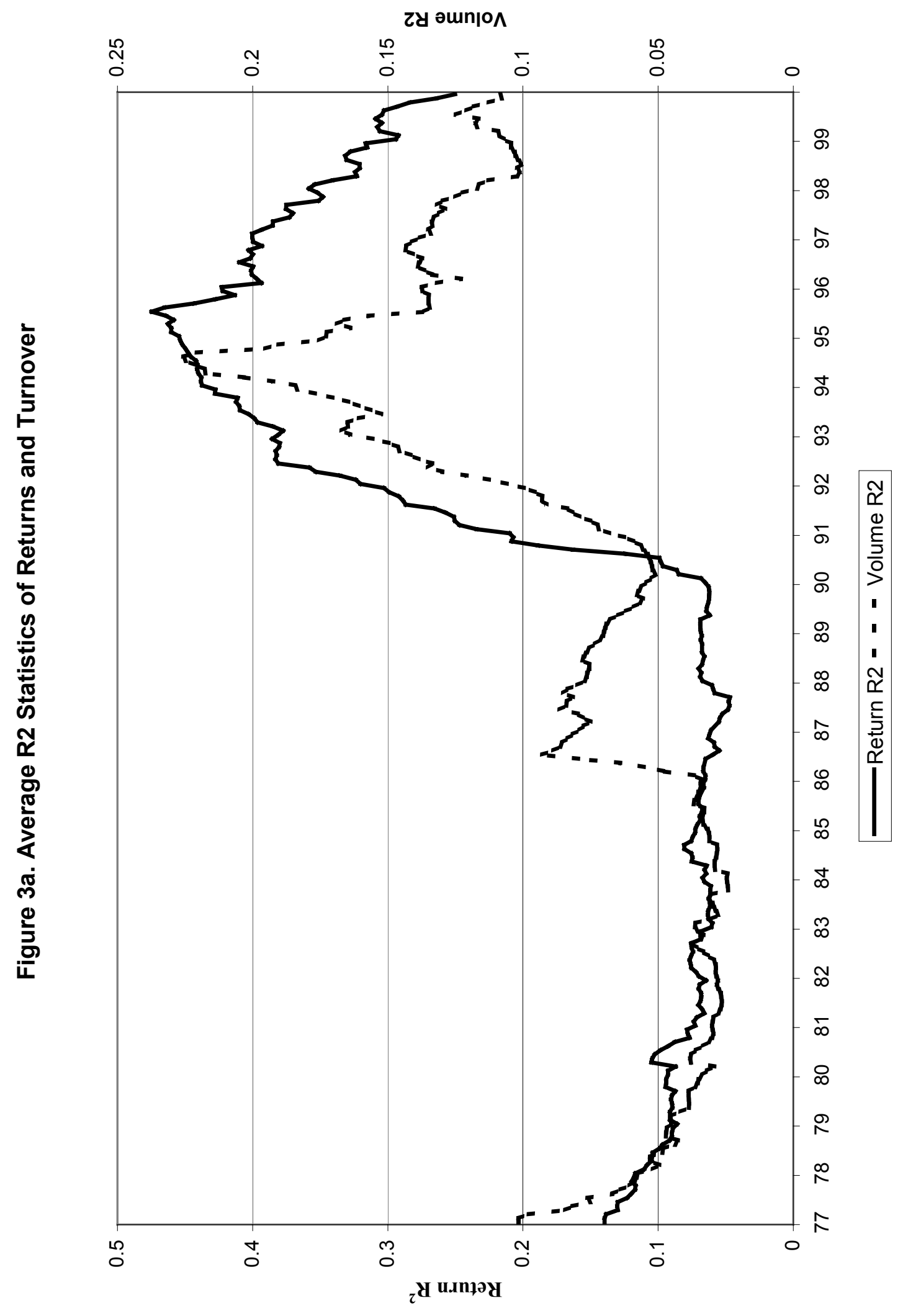




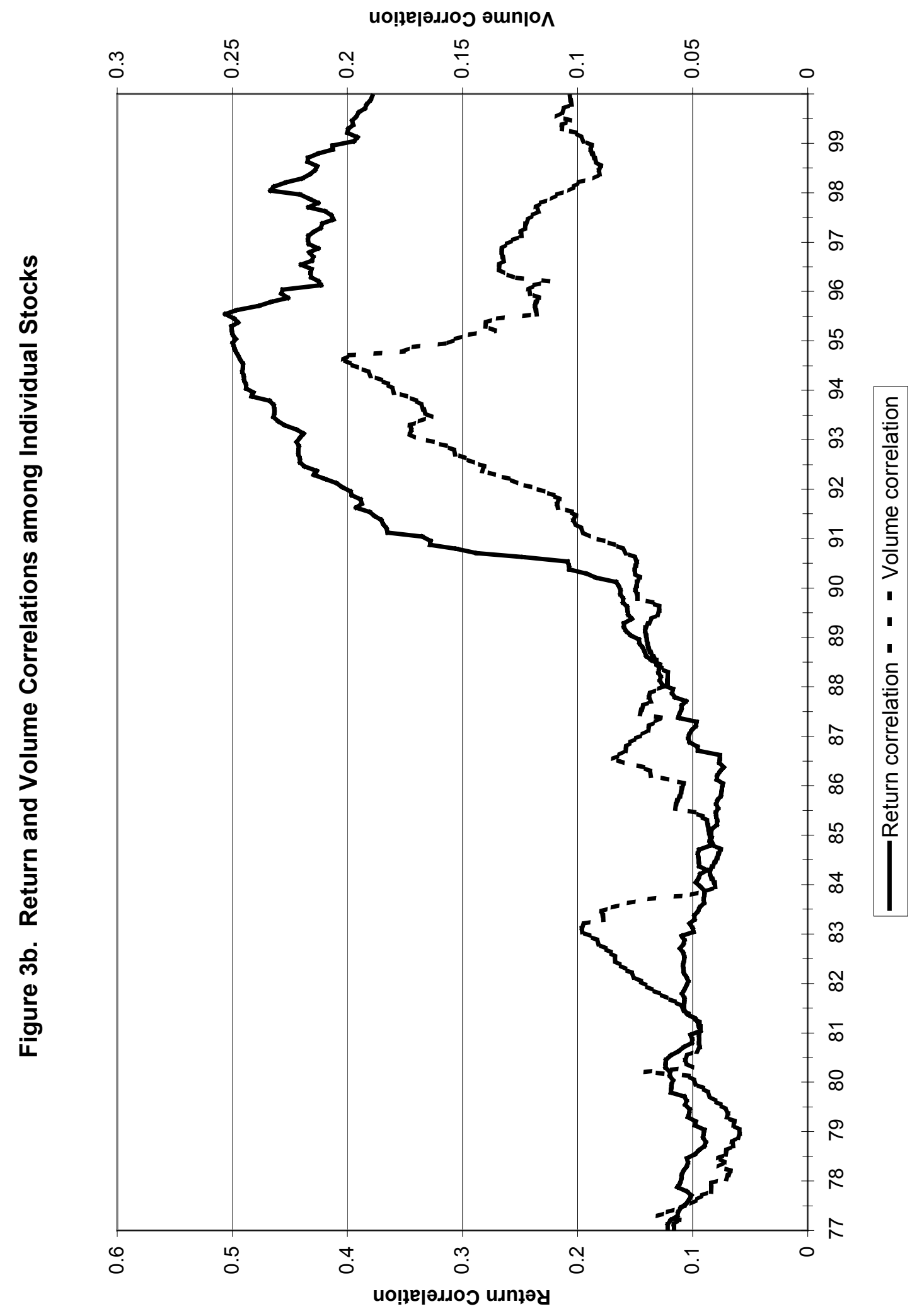




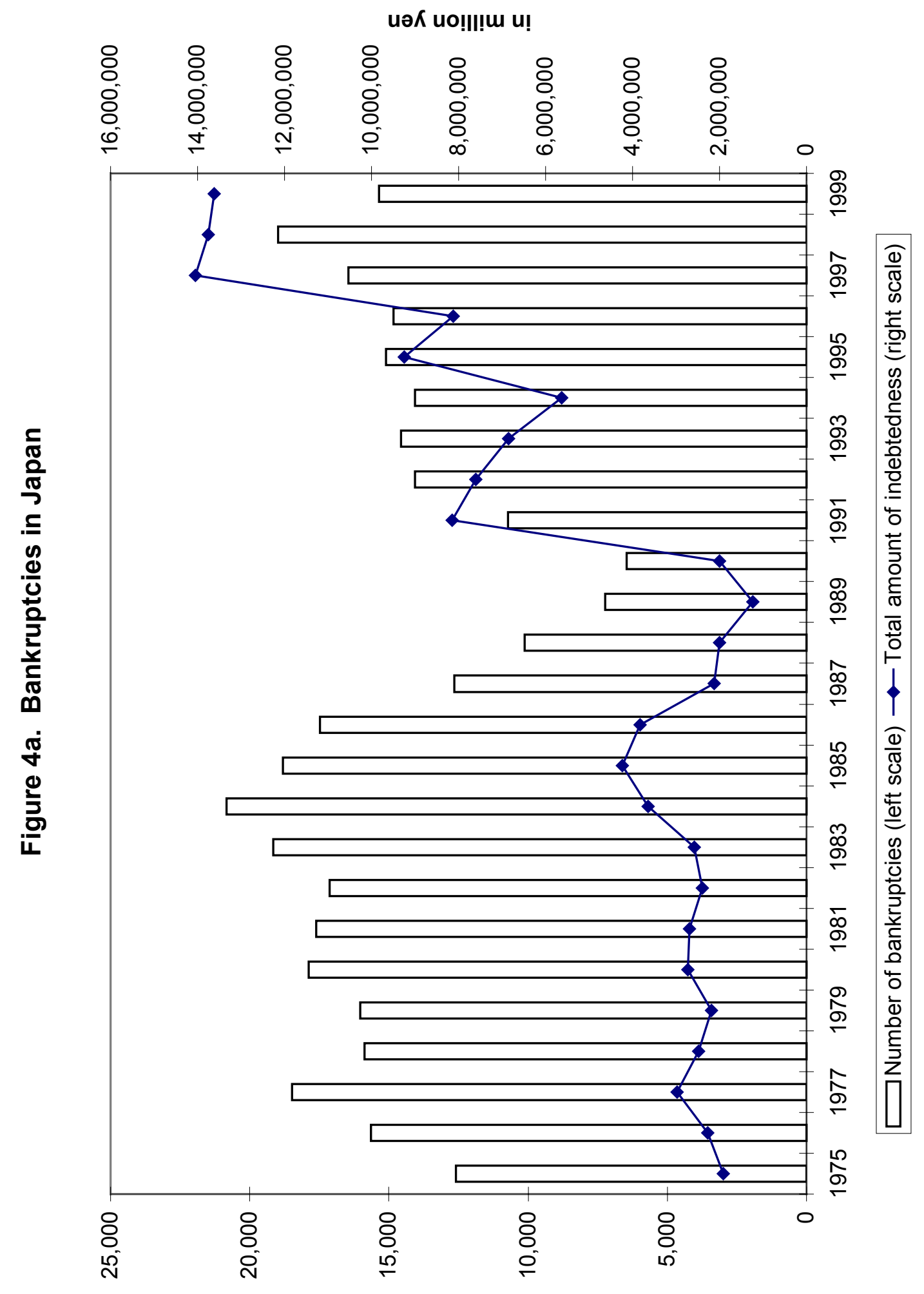




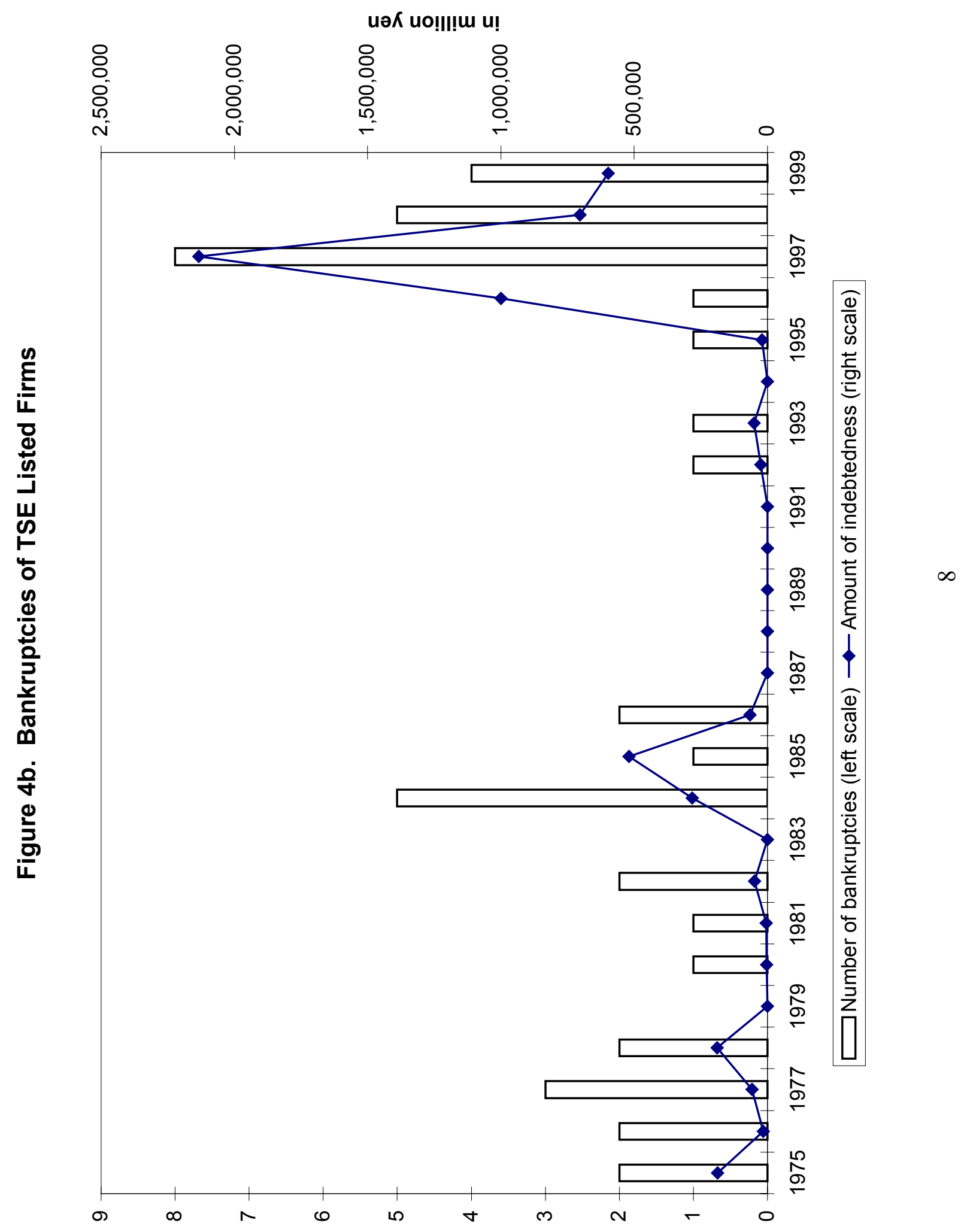




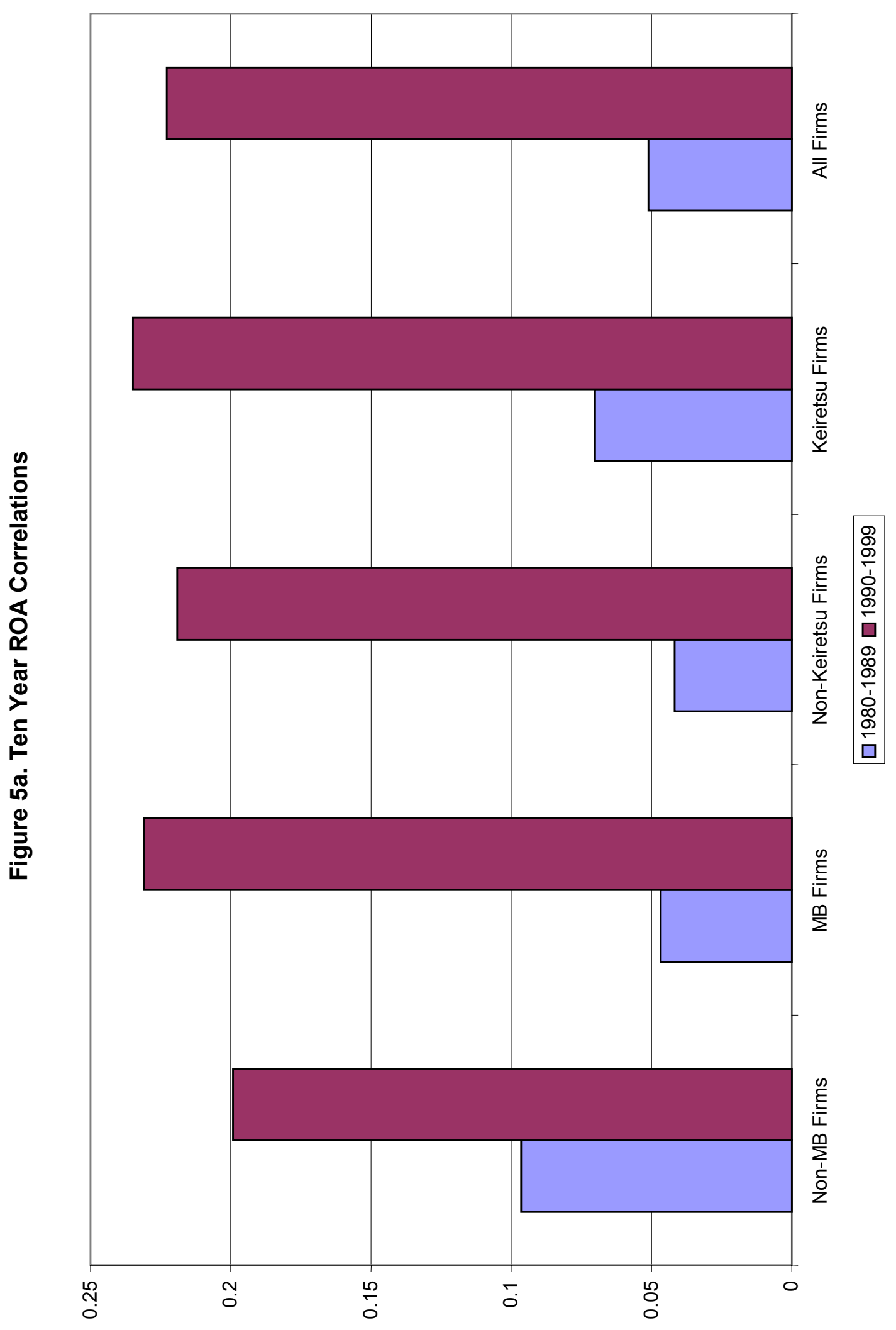




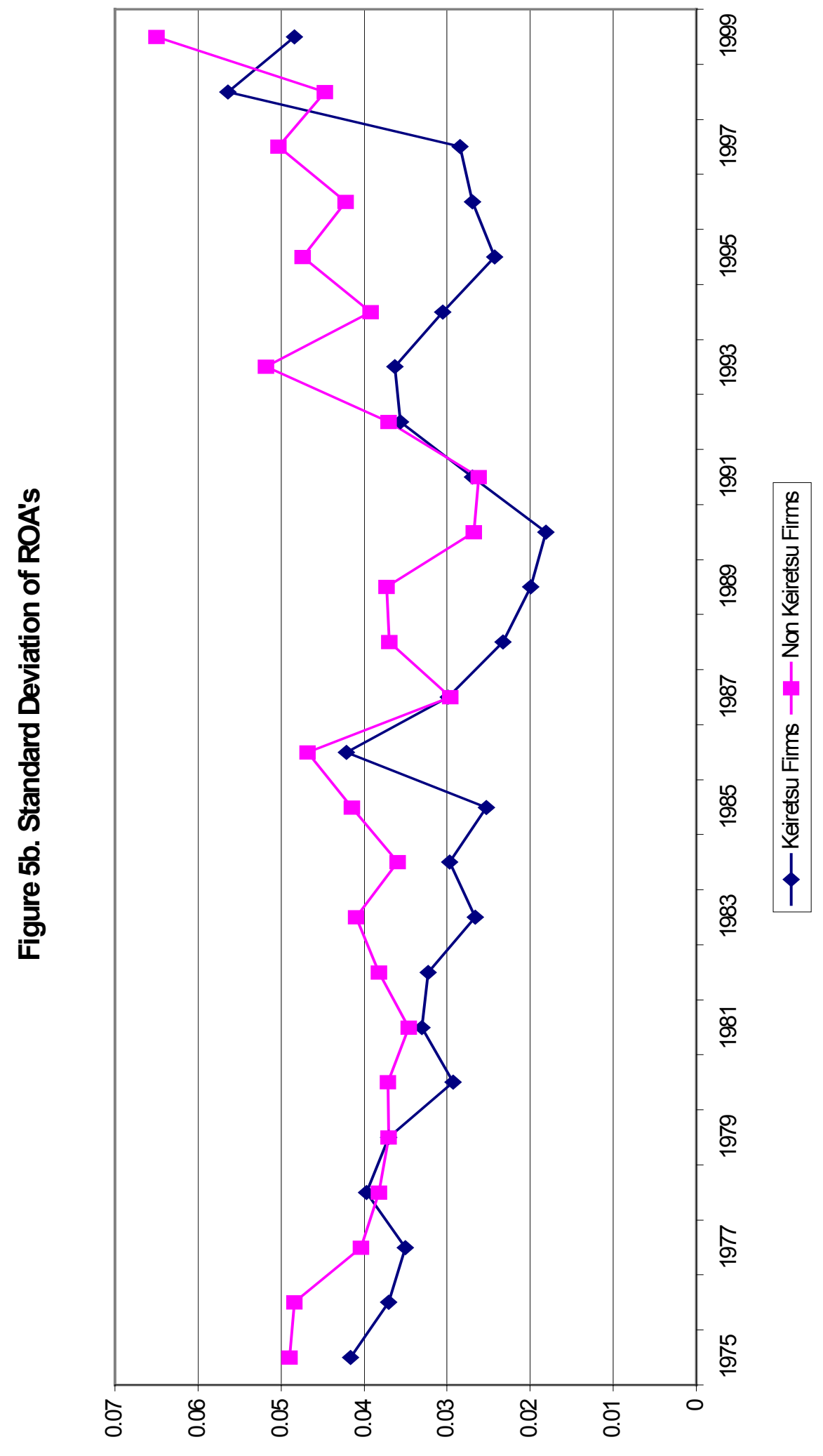




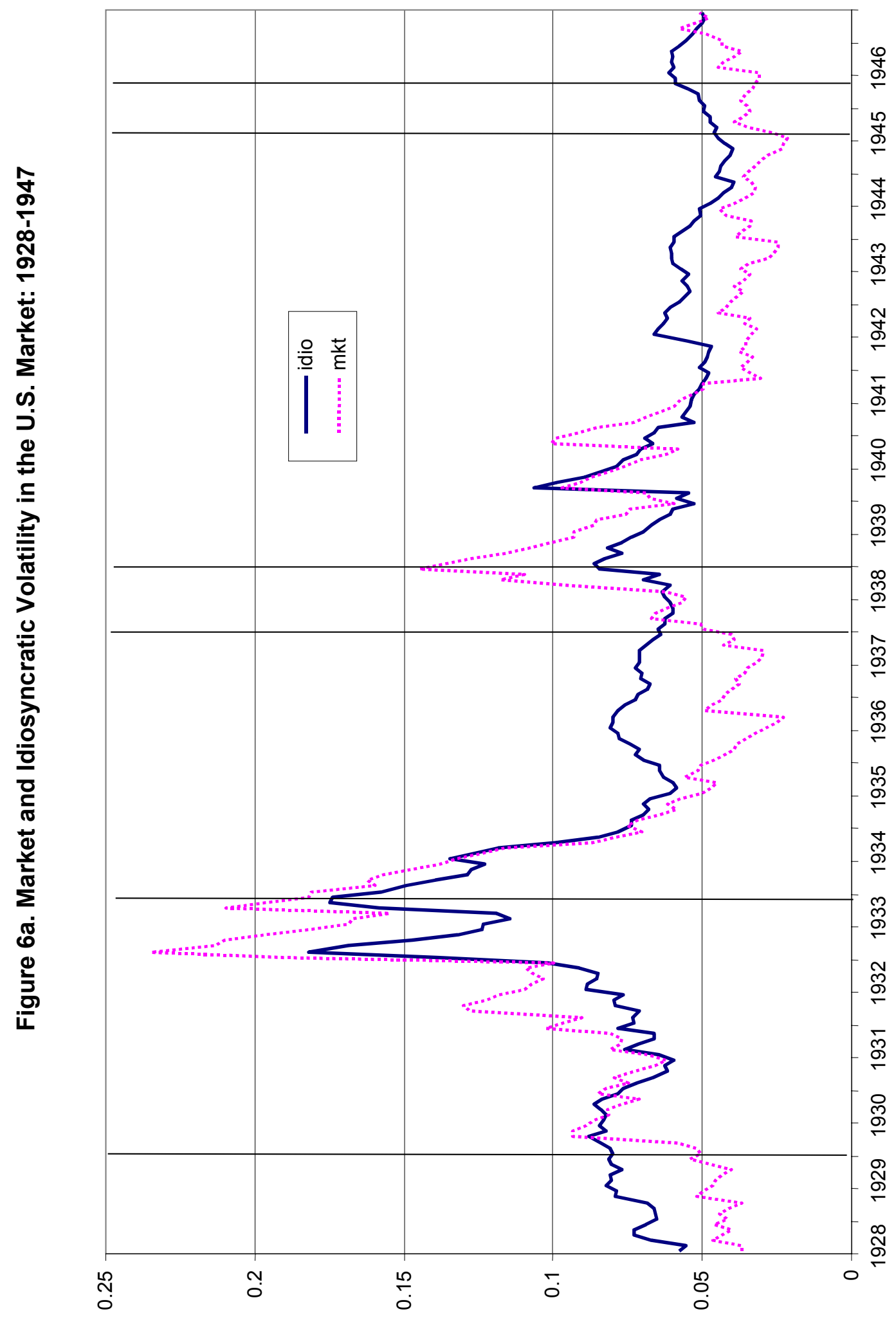




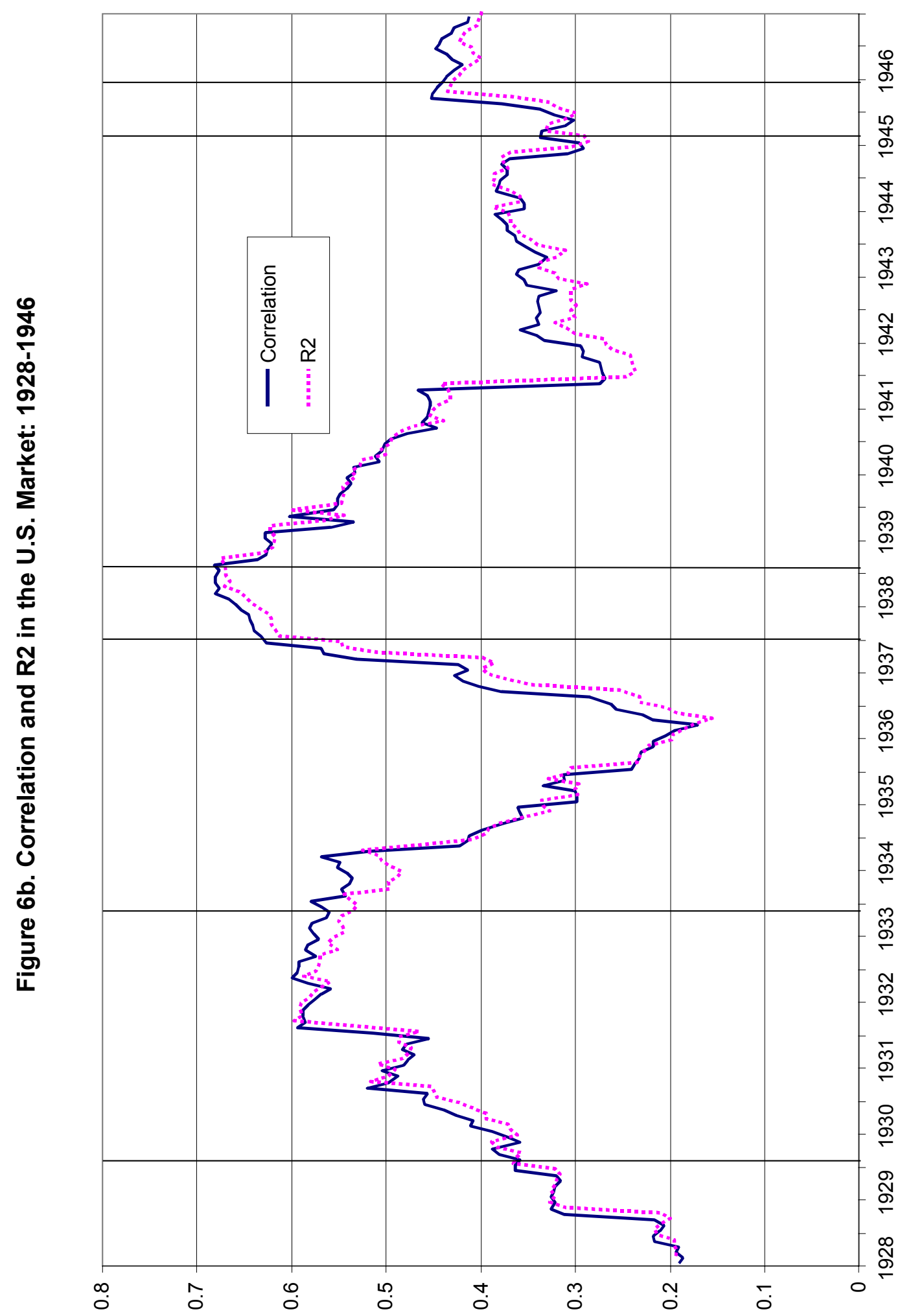

